\title{
EXPLAINING THE RATE SPREAD ON CORPORATE BONDS
}

\author{
by Edwin J. Elton,* Martin J. Gruber,* \\ Deepak Agrawal** and Christopher Mann**
}

Revised September 24, 1999

* Nomura Professors of Finance, Stern School of Business, New York University

** Doctoral students, Stern School of Business, New York University 


\begin{abstract}
The purpose of this article is to explain the spread between spot rates on corporate and government bonds. We find that the spread can be explained in terms of three elements: (1) compensation for expected default of corporate bonds (2) compensation for state taxes since holders of corporate bonds pay state taxes while holders of government bonds do not, and (3) compensation for the additional systematic risk in corporate bond returns relative to government bond returns. The systematic nature of corporate bond return is shown by relating that part of the spread which is not due to expected default or taxes to a set of variables which have been shown to effect risk premiums in stock markets Empirical estimates of the size of each of these three components are provided in the paper. We stress the tax effects because it has been ignored in all previous studies of corporate bonds.
\end{abstract}




\section{INTRODUCTION}

In recent years there have been a number of papers examining the pricing of corporate debt. These papers have varied from theoretical analysis of the pricing of risky debt using option pricing theory, to a simple reporting of the default experience of various categories of risky debt. The vast majority of the articles dealing with corporate spreads have examined yield differentials of corporate bonds relative to government bonds. The purpose of this article is to re-examine and explain the differences in the rates offered on corporate bonds and those offered on government bonds (spreads), and in particular to examine whether there is a risk premium in corporate bond spreads and, if so, why does it exist. As part of our analysis, we argue that differences in corporate and government rates should be measured in terms of spot rates (yield to maturity on zero coupon debt) rather than yield to maturity on coupon bonds.

Differences in spot rates between corporate and government bonds (the corporate spot spreads) differ across rating classes and should be positive for each rating class for the following four reasons:

1. Expected default loss -- some corporate bonds will default and investors require a higher promised payment to compensate for the expected loss from defaults.

2. Tax premium - interest payments on corporate bonds are taxed at the state level while interest payments on government bonds are not. 
3. Liquidity effect / corporate bonds have higher and more volatile bid ask spreads and there may be a delay in finding a counter-party for a transaction. Investors need to be compensated for these risks.

4. Risk premium - The return on corporate bonds are riskier than the returns on government bonds, and investors may require a premium for the higher risk.

The only controversial part of the above analysis is the fourth point. Some authors in their analysis assume that the risk premium is zero in the corporate bond market. ${ }^{1}$

This paper is important because it provides the reader with explicit estimates of each of the components of the spread between corporate bond spot rates and government bond spot rates. While some studies have examined losses from default, to the best of our knowledge, none of these studies has examined tax effects or made the size of compensation for systematic risk explicit. Tax effects occur because the investor in corporate bonds is subject to state taxes on payments while government bonds are not subject to state taxes. Thus, corporate bonds have to

$1 \quad$ Most of the models using option pricing techniques assume a zero risk premium. Bodie, Kane, and Marcus (1993) assume the spread is all default premium. See also Fons (1994) and Cumby and Evans (1995). On the other hand, rating based pricing models like Jarrow Lando and Turnbull (1997) and Das-Tufano (1996) assume that any risk premium impounded in corporate spreads is captured by adjusting transition probabilities. 
offer a higher pre-tax return to yield the same after tax return. This tax effect has been ignored in the empirical literature on corporate bonds. In addition, past research has ignored or failed to measure whether corporate bond prices contain a risk premium above and beyond the expected loss from default. We find that the risk premium is a large part of the spread. We show that corporate bonds require a risk premium because spreads and returns vary systematically with the same factors as common stock returns. If investors in common stocks require compensation for this risk so should investors in corporate bonds. The source of the risk premium in corporate bond prices has long been a puzzle to researchers and this study is the first explanation for its size and existence.

Why do we care about estimating the spread components separately rather than simply pricing corporate bonds off a spot yield curve or a set of estimated risk neutral probabilities? First, we want to know the forces driving prices and not simply what prices are. Second, for an investor thinking about purchasing corporate bonds, the size of each component embodied in market prices will affect the decision on whether to purchase the bonds.

To illustrate this last point, consider the literature that indicates that low-rated bonds produce higher average returns than bonds with higher ratings. ${ }^{2}$ Further, consider the literature, such as Blume, Keim and Patel (1991), that shows the standard deviation of returns is no higher for low-rated bonds than it is for high-rated bonds. What does this evidence indicate for investment? This evidence has been used to argue that low-rated bonds are attractive investments. Our decomposition of corporate spreads into expected default loss, tax premium

2 See for example Altman (1989), Goodman (1989), Blume, Keim and Patel (1991), and Cornell and Green (1991). 
and risk premium shows that these results need to be interpreted differently. As we will show, the tax and risk premium are substantial, and are higher for low rated bonds than for high rated bonds, and thus the conclusion that low-rated bonds are superior investments may be incorrect for almost all investors.

This paper proceeds as follows: In the first section, we present a description of the data employed in this study and how our sample is constructed. In the second section we present the methodology for, and present the results of, extracting government and corporate spot rates from data on individual coupon bonds. We then examine the differentials between the spot rates which exist for corporate bonds and those that exist for government bonds. We find that the corporate spot spreads are higher for lower rated bonds, and that they tend to go up with maturity. The shape of the spot spread curve can be used to differentiate between alternative corporate bond valuation models derived from option pricing theory. In this section we also examine the ability of estimated spot rates to price corporate bonds. How bad is the approximation? We answer this by examining pricing errors on corporates using the spot rates extracted from our sample of corporate bonds.

The remainder of this paper is concerned with decomposing corporate spreads into parts that are due to expected default loss, tax premium, and risk premium. In the third section of this paper we model and estimate that part of the corporate spread which is due to expected default loss. If we assume, for the moment, that there is no risk premium, then we can value 
corporate bonds under a risk neutral assumption using expected default losses. ${ }^{3}$ This risk neutral assumption allows us to construct a model of what the corporate spot spread would be if it were solely due to expected default losses and to estimate it using historical data on rating transition probabilities, default rates, and recovery rates after default. The spot rate spread curves estimated by incorporating only expected losses due to default are well below the observed spot spread curve and they do not increase as we move to lower ratings as fast as actual spot curves do. The difference between these curves can only be due to taxes and possibly a risk premium.

In the next section of this paper we examine the impact of both the expected default loss and the tax premium on corporate spot spreads. In particular, we build taxes into the risk neutral valuation model developed earlier and estimate the set of spot rates that should be used to discount promised cash payments when taxes and expected default losses are taken into consideration. We then show that using the best estimate of tax rates, historical rating transition probabilities, and recovery rates, actual corporate spot spreads are still much higher than taxes and default premiums can account for. Furthermore, fixing taxes at a rate that explains the spread on AA debt still doesn't explain the A and BBB spreads. The difference in spreads across rating categories has to be due to the presence of a risk premium. Also, to explain empirical spreads, the compensation the investor requires for risk must be higher for lower rated debt and for longer maturity bonds.

3 We also temporarily ignore the tax disadvantage of corporate bonds relative to government bonds in this section. 
The last section of this paper presents direct evidence of the existence of a risk premium by first relating the time series of that part of the spreads that is not explained by expected loss or taxes to a set of variables that are generally considered systematic factors impacting risk in the literature of Financial Economics and then by relating cross sectional differences in spreads to sensitivities of each spread to these variables. We have already shown that the default premium and tax premium can only partially account for the difference in corporate spreads. In this section we present direct evidence that there is a risk premium by showing that part of the corporate spread, not explained by defaults or taxes, is related to systematic factors that are generally believed to be priced in the market.

\section{DATA}

Our bond data is extracted from the Lehman Brothers Fixed Income database distributed by Warga (1998). This database contains monthly price, accrued interest, and return data on all investment grade corporate and government bonds. In addition, the database contains descriptive data on bonds including coupon, ratings, and callability.

A subset of the data in the Warga database is used in this study. First, all bonds that were matrix-priced rather than trader-priced are eliminated from the sample. Employing matrix prices might mean that all our analysis uncovers is the formula used to matrix price bonds rather than the economic influences at work in the market. Eliminating matrix priced bonds leaves us with a 
set of prices based on dealer quotes. This is the same type of data as that contained in the standard academic source of government bond data: the CRSP government bond file. ${ }^{4}$

Next, we eliminate all bonds with special features that would result in their being priced differently. This means we eliminate all bonds with options (e.g,. callable or sinking fund), all corporate floating rate debt, bonds with an odd frequency of coupon payments, government flower bonds and index-linked bonds.

Next, we eliminate all bonds not included in the Lehman Brothers bond indexes because researchers in charge of the database at Lehman Brothers indicated that the care in preparing the data was much less for bonds not included in their indexes. This results in eliminating data for all bonds with a maturity of less than one year.

Finally, we eliminate bonds where the price data or return data was problematic. This involved examining the data on bonds which had unusually high pricing errors when priced using the spot curve. Bond pricing errors were examined by filtering on errors of different sizes and a

$4 \quad$ The only difference in the way CRSP data is constructed and our data is constructed is that over the period of our study, CRSP used an average of bid/ask quotes from five primary dealers called randomly by the New York Fed rather than a single dealer. However, comparison of a period when CRSP data came from a single dealer and also from the five dealers surveyed by the Fed showed no difference in accuracy (Sarig and Warga (1989)). Also in Section II, the errors in pricing government bonds when spots are extracted from the Warga data are comparable to the errors when spots are extracted from CRSP data. Thus our data should be comparable in accuracy to the CRSP data. 
final filter rule of $\$ 5$ was selected. ${ }^{5}$ Errors of $\$ 5$ or larger are unusual, and this step resulted in eliminating 2,710 bond months out of our total sample of 95,278 bond months. Examination of the bonds that are eliminated because of large differences between model prices using estimated spots and recorded prices shows that large differences were caused by the following:

1. The price was radically different from both the price immediately before the large error and the price after the large error. This probably indicates a mistake in recording the data.

2. The company issuing the bonds was going through a reorganization that changed the nature of the issue (such as its interest rate or seniority of claims), and this was not immediately reflected in the data shown on the tape, and thus the trader was likely to have based the price on inaccurate information about the bond's characteristics.

3. A change was occurring in the company that resulted in the rating of the company changing so that the bond was being priced as if it were in a different rating class.

We need to examine one further issue before leaving this section. The prices in the Warga database are bid prices as are the institutional price data reported in DRI or Bloomberg. Since

5 The methodology used to do this is described later in this paper. We also examined $\$ 3$ and $\$ 4$ filters. Employing a $\$ 3$ or $\$ 4$ filter would have eliminated few other bonds, since there were few intermediate-size errors, and we could not find any reason for the error when we examined the few additional bonds that would be eliminated. 
the difference in the bid and ask price in the government market is less than this difference in the corporate market, using bid data would result in a spread between corporate and government bonds even if the price absent the bid ask spread were the same. How big is this bias?

Discussion with researchers at Lehman Brothers indicates that for the bonds in our sample (active corporate issues) the average spread was about 25 cents per $\$ 100$. Elton and Green (1998) show the average spread for governments is 5 cents. Thus, the bias is (25 -5)/2 or about 10 cents. We will not adjust the spreads shown in our tables but the reader should realize they are about 10 cents too high.

\section{TERM STRUCTURE OF SPOTS?}

In this section of the paper, we examine the difference in spot rates between corporate bonds and Treasury bonds over various maturities. Our analysis has three parts. In the first part, we explain why we examine spot rates rather than yield to maturity. In the second part, we present the methodology for extracting spot rates and present the term structure of spreads over our sample period. In the third part, we examine the pricing errors which result from valuing corporate and government bonds using estimated spot rates.

\section{A. Why Spots?}

Most previous work on corporate spreads has defined corporate spread as the difference 
between the yield to maturity on a corporate bond (or an index of corporate bonds) and the yield to maturity on a government bond (or an index of government bonds) of the same maturity. This tradition goes back at least as far as Fisher (1959). Although most researchers now recognize that there are problems with using yield to maturity, given the long tradition, a few comments might be helpful.

The basic reason for using spots rather than yield to maturity is that arbitrage arguments hold with spot rates, not yield to maturity. A spot rate is the yield to maturity or discount rate on a zero coupon bond. Since a riskless coupon paying bond can always be expressed as a portfolio of zeros, it is also the rate that must be used to discount cash flows on riskless coupon paying debt to prevent arbitrage. Thus, finding two riskless coupon paying bonds with different yields to maturity and the same maturity date does not indicate an arbitrage opportunity, whereas finding two riskless zeros with different spot rates and the same maturity indicates a profitable arbitrage. In addition many authors use yield to maturity on an index of bonds. Published indexes use a weighted average of the yields of the component bonds to compute a yield to maturity on the index. Yields are not additive, so this is not an accurate way of calculating the yield to maturity on an index.

When we consider corporate bonds, another problem arises that does not hold with riskless bonds; the spread in the yield to maturity on corporates relative to governments can change even if there is no change in any of the fundamental factors that should affect spread, 
namely taxes, default rates and risk premiums. In particular, the difference in the yield to maturity on corporates and the yield to maturity on governments is a function of the shape of the term structure of governments. Inferences made about changes in risk in the corporate market because of the changing spread in yield-to-maturity may be erroneous since the changes can be due simply to changes in the shape of the government term structure. Thus, in this paper we examine spreads in spot rates. ${ }^{6}$

\section{B. The Term Structure of Corporate Spreads}

In this section, we examine the corporate government spread for bonds in different rating classes and with different maturities. While there are several methods of determining spot rates from a set of bond prices, both because of its simplicity and proven success in deriving spots, we have adopted the methodology put forth by Nelson and Siegel (N\&S). ${ }^{7}$ The N\&S methodology involves fitting the following equations to all bonds in a given risk category to obtain the spot rates that are appropriate for any point in time.

$6 \quad$ Spot rates on promised payments may not be a perfect mechanism for pricing risky bonds because the law of one price will hold as an approximation when applied to promised payments rather than risk adjusted expected payments. See Duffie and Singleton (1997) for a description of the conditions under which using spots to discount cash flows is consistent with no arbitrage.

7 See Nelson and Siegal (1987). For comparisons with other procedures, see Green and Odegaard (1997) and Dahlquist and Svensson (1996). We also investigated the McCulloch cubic spline procedure and found substantially similar results throughout our analysis. The Nelson and Siegal model was fit using standard Gauss-Newton non-linear least squared methods. 


$$
\begin{aligned}
& D_{t}=e^{-r_{t} t} \\
& r_{t}=a_{o}+\left(a_{1}+a_{2}\right)\left[\frac{1-e^{-a_{3} t}}{a_{3} t}\right]-a_{2} e^{-a_{3} t}
\end{aligned}
$$

Where

$D_{t}=$ the present value as of time zero for a payment that is received t periods in the future $r_{t}=$ the spot rate at time zero for a payment to be received at time $\mathrm{t}$

$a_{0,} a_{1}, a_{2}$, and $a_{3}=$ parameters of the model.

The N\&S procedure is used to estimate spot rates for different maturities for both Treasury bonds and for bonds within each corporate rating class for every month over the time period January 1987 through December 1996. This estimation procedure allows us on any date, to use corporate coupon and principle payments and prices of all bonds within the same rating class to estimate the full spot yield (discount rate) curve which best explains the prices of all bonds in that rating class on that date. ${ }^{8}$

$8 \quad$ The Nelson and Siegal (1987) and McCulloch (1971) procedures have the advantage of using all bonds outstanding within any rating class in the estimation procedure, therefore, lessening the affect of sparse data over some maturities and lessening the affect of pricing errors on one or more bond. The cost of these procedures is that they place constraints on the shape of the yield curve. However, they do allow for a wide variety of general shapes including upward sloping, downward sloping, and humped curves. 
As mentioned earlier, the data we use on risky bonds only exist for bonds of maturity longer than one year. In addition, for most of the ten-year period studied, the number of AAA bonds that existed and were dealer quoted was too small to allow for accurate estimation of a term structure. Finally, data on corporate bonds rated below BBB was not available for most of the time period we studied. ${ }^{9}$ Because of this, spot rates are only computed for bonds with maturities between two to ten years for Treasury, AA, A and BBB-rated bonds. Initial examination of the data showed that the term structure for financials was slightly different from the term structure for industrials, and so in this section the results for each sector are reported separately. ${ }^{10}$

We are concerned with measuring differences between corporate and government returns. The corporate spread we examine is the difference between the spot rate on corporate bonds in a particular rating class and spot rates for Treasury bonds of the same maturity. Table I presents Treasury spot rates as well as corporate spreads for our sample of the three rating classes discussed earlier: AA, A and BBB for maturities from two to ten years. In Panel A of Table I, we have presented the average difference over our ten-year sample period, 1987-1996. In Panels B and $\mathrm{C}$ we present results for the first and second half of our sample period. We expect these

$9 \quad$ For some of our analysis, we used Moodys data and for part S\&P data. To avoid confusion we will always use $S \& P$ classifications though we will identify the sources of data. When we refer to BBB bonds as rated by Moodys, we are referring to the equivalent Moodys class, namely Baa.

10 This difference is not surprising because industrial and financial bonds differ both in their sensitivity to systematic influences and idiosyncratic shocks which occurred over the time period. 
differences to vary over time.

There are a number of interesting results reported in these tables. Note that in general the corporate spread for a rating category is higher for financials than it is for industrials. For both financial and industrial bonds, the corporate spread is higher for lower-rated bonds for all spots across all maturities in both the ten-year sample and the five-year subsamples. Bonds are priced as if the ratings capture real information. To see the persistence of this influence, Figure 1 presents the time pattern of the spreads on six-year spot payments for AA, A and BBB industrial bonds month by month over the ten-years of our sample. Note that the curves never cross. A second aspect of interest is the relationship of corporate spread to the maturity of the spot rates. An examination of Table I shows that there is a general tendency for the spreads to increase as the maturity of the spot lengthens. However, for the ten years 1987-1996 and each five year subperiod the spread on BBB industrial bonds exhibits a humped shape.

The results we find can help differentiate between the corporate debt valuation models derived from option pricing theory. The upward sloping spread curve for high-rated debt is consistent with the models of Merton (1974), Jarrow, Lando and Turnbull (1997), Longstaff and Schwartz (1995), and Pitts and Selby (1983). It is inconsistent with the humped shape derived by Kim, Ramaswamy and Sundaresan (1987). The humped shape for BBB industrial debt is predicted by Jarrow, Lando and Turnbull (1997) and Kim, Ranaswamy and Sundaresan (1987), and is consistent with Longstaff and Schwartz (1995) and Merton (1974) if BBB is considered 
low-rated debt. ${ }^{11}$

We will now examine the results of employing spot rates to estimate bond prices.

\section{Fit Error}

One test of how well the spot rates extracted from corporate yield curves explain prices in the corporate market is to directly compare actual prices with the model prices derived by discounting coupon and principal payments at the estimated spot rates. Model price and actual price can differ because of errors in the actual price and because bonds within the same rating class, as defined by a rating agency, are not homogenous in risk. We calculate model prices for each bond in each rating category every month using the spot yield curves estimated for that rating class in that month. Each month average error (error is measured as actual minus theoretical price) along with the square root of the average squared error is calculated. This is then averaged over the full ten years and separately for the first and last five years for each rating category. The average error for all rating classes is very close to zero being less than one cent on a hundred dollar bond. The root mean square error is a measure of the variance of errors within each rating class. The average root mean squared error between actual price and estimated price

11 While the BBB industrial curve is consistent with the models that are mentioned, estimated default rates shown in Table IV are inconsistent with the assumptions these models make. Thus the humped BBB industrial curve is inconsistent with spread being driven only by defaults. 
is shown in Table II. The average root mean square error of 21 cents per 100 dollars for Treasuries is comparable to the average root mean squared error found in other studies. Elton and Green (1998) showed average errors of about 16 cents per $\$ 100$ using GovPX data over the period June 1991 to September 1995. GovPX data are trade prices, yet the difference in error between the studies is quite small. Green and Odegaard (1997) used the Cox, Ingersoll and Ross (1987) procedure to estimate spot rates using data from CRSP. While their procedure and time period are different from ours, their errors again are about the same as those we find for government bonds in our data set (our errors are smaller). The data set and procedures we are using seem to produce comparable size errors in pricing government bonds to those found by other authors.

The average root mean square pricing errors become larger as we examine lower grade of bonds while the average error does not change. Average root mean square pricing errors are over twice as large for AA's as for Treasuries. The root mean square pricing errors for BBB's are almost twice those of AA's, with the errors in A's falling in between. Thus default risk leads not only to higher spot rates, but also to greater uncertainty as to the appropriate value of the bond, and this is reflected in a higher root mean square error (variance of pricing errors). This is an added source of risk and may well be reflected in higher risk premiums, a subject we investigate shortly. ${ }^{12}$

\footnotetext{
${ }^{12}$ In a separate paper, we explore whether the difference in theoretical price and invoice price is random or related to bond characteristics. Bond characteristics do explain some of the differences but the characteristics and relationships do not change the results in this paper.
} 


\section{DEFAULT SPREADS}

In this section, we will examine the magnitude of the spread under risk neutrality with the tax differences between corporates and governments ignored. Later we will introduce tax differences and examine whether default spreads and taxes together are sufficient to explain the observed spot spread.

If investors were risk neutral (risk neutrality), the expected cash flows could be discounted at the government bond rate to obtain the corporate bonds' value. Consider a twoperiod bond using expected cash flows and risk neutrality. For simplicity, assume its par value at maturity is $\$ 1$. We wish to determine its value at time zero and we do so recursively by valuing it first at time 1 (as seen at time 0 ) and then at time 0 .

Its value as of time one when it is a one-period bond has three component parts: the value of the expected coupon to be received at 2 , the value of the expected principal to be received at 2 if the bond goes bankrupt at 2 , and the value of the principal if the bond survives where all expectations are conditional on the bond surviving to period 1 . This can be expressed as ${ }^{13}$ $V_{12}=\left[C\left(1-P_{2}\right)+a P_{2}+\left(1-P_{2}\right)\right] e^{-r_{12}^{G}}$

13 The assumption of receiving a constant proportion of face value has been made in the literature by Brennen and Schwartz (1980) and Duffie (1998). We are assuming that default payment occurs at the time of default. This is consistent with the evidence that default occurs because of an inability to meet a payment. We also assume that recovery rate is a percentage of par. This is how all data is collected (e.g. Altman (1997)). 
Where

$C$ is the coupon rate

$P_{t}$ is the probability of bankruptcy in period t conditional on no bankruptcy in an earlier period

$a$ is the recovery rate assumed constant in each period

$r_{t t+1}^{G}$ is the forward rate as of time 0 from $t$ to $t+1$ for government (risk-free) bonds ${ }^{14}$

$V_{t T}$ is the value of a $T$ period bond at time t given that it has not gone bankrupt in an earlier

period.

Alternatively, valuing the bond using promised cash flows, its value is:

$V_{12}=(C+1) e^{-r_{12}^{C}}$

Where

1. $r_{t+1}^{C}$ Is the forward rate from $t$ to $t+1$ for corporate bonds

Equating the two values and rearranging to solve for the difference between corporate and government forward rates, we have:

$e^{-\left(r_{12}^{C}-r_{12}^{G}\right)}=\left(1-P_{2}\right)+\frac{a P_{2}}{(1+C)}$

14 We discount at the forward rate. For this is the rate which can be contracted at time zero for moving money across time. 
at time zero, the value of the two-period bond using risk neutral valuation is

$\left.V_{02}=\left[C\left(1-P_{1}\right)+a P_{1}+\left(1-P_{1}\right) V_{12}\right)\right] e^{-r_{01}^{G}}$

and using promised cash flows, its value is

$V_{02}=\left[C+V_{12}\right] e^{-r_{01}^{C}}$

Equating these expressions for $\mathrm{V}_{02}$ and solving for the difference in one period spot (or forward)

rates, we have

$$
e^{-\left(r_{01}^{C}-r_{01}^{G}\right)}=\left(1-P_{1}\right)+\frac{a P_{1}}{V_{12}+C}
$$

In general, in period t the difference in forward rates is ${ }^{15}$

15 The difference in forward rates may vary across bonds with different coupons, even for bonds of the same rating class because, as discussed earlier, arbitrage on promised payments is an approximation which holds exactly only under certain assumptions (see Duffie and Singleton (1999)). Thus, the estimates of spot rates obtained empirically are averages across bonds with different coupons, and one single spot rate does not hold exactly for all bonds. Nevertheless, given the size of the pricing error found in the previous section, assuming one rate is a good approximation. 


$$
e^{-\left(r_{t+1}^{C}-r_{t+1}^{G}\right)}=\left(1-P_{t+1}\right)+\frac{a P_{t+1}}{V_{t+1 T}+C}
$$

Where

1. $\quad V_{T T}=1$

We can now use equation (6) to obtain estimates of the default spreads on corporate bonds. The inputs to equation (6) were obtained as follows: First, the coupon was set so that a ten-year bond with that coupon would be selling close to par in all periods. ${ }^{16}$ Then, estimates of default rates and recovery rates were computed. To estimate future default rates, we used a transition matrix and a default vector. We employed two separate estimates of the transition matrix, one estimated by S\&P (See Altman (1997)) and one estimated by Moody’s (Carty \& Fons(1994)). ${ }^{17}$ These are the two principal rating agencies for corporate debt. The transition matrixes are shown in Table III.

16 We examined alternative reasonable estimates for coupon rates and found only second order effects in our results. While this might seem inconsistent with equation (6), note that from the recursive application of equation (1) and (2) changes in $\mathrm{C}$ are largely offset by opposite changes in $\mathrm{V}$.

17 Each row of the transition matrix shows the probability of having a given rating in one year contingent on starting with the rating specified by the row. 
The probability of default given a particular rating at the beginning of the year is shown as the last column in Table III. Given the transition matrix and an initial rating, we can estimate the probability of a default in each future year, given that the bond has not defaulted prior to that year. In year one, the probability of default can be determined directly from the transition matrix and default vector, and is whatever proportion of that rating class defaults in year one. To obtain year two defaults, we first use the transition matrix to calculate the ratings going into year two for any bond starting with a particular rating in year 1 . Year two defaults are then the proportion in each rating class times the probability that a bond in that class defaults by year-end. ${ }^{18}$ Table IV shows the default probabilities by age and initial rating class for the Moody's and S\&P transition data. The entries in this table represent the probability of default for any year $t$ given an initial rating and given that the bond was not in default at time $\mathrm{t}-1$.

Table IV shows the importance of rating drift over time on default probabilities. The marginal probability of default increases for the high rated debt and decreases for the low rated debt. This occurs because bonds change rating classes over time. ${ }^{19}$ For example, a bond rated AAA by S\&P has zero probability of defaulting one year later. However, given that it hasn't previously defaulted, its probability of defaulting twenty years latter is $.206 \%$. In the intervening years some of the bonds originally rated AAA have migrated to lower-rated categories where

18 Technically it is the last column of the squared transition matrix divided by one minus the probability of default in period 1 .

19 These default probabilities as a function of age are high relative to prior studies e.g., Altman (1997), Moody's (1998). 
there is some probability of default. At the other extreme, a bond originally rated CCC has a probability of defaulting equal to $22.052 \%$ in the next year, but if it survives twenty more years the probability of default in the next year is only $2.928 \%$. If it survives twenty years, the bond is likely to have a higher rating. Despite this drift, 20 years later bonds which were rated very highly at the beginning of the period tend to have a higher probability of staying out of default after twenty years than do bonds which had a low rating. However rating migration means this does not hold for all risk classes. For example, note that after 12 years the conditional probability of default for CCC's is lower than the default probability for B's. Why? Examining Table III shows that the odds of being upgraded to investment grade conditional on not defaulting is higher for CCC than B. Eventually, bonds that start out as CCC and continue to exist will be higher rated than those that start out as B's. In short, the small percentage of CCC bonds that continue to exist for many years, end up at higher ratings on average than the larger percentage of B bonds that continue to exist for many years.

In addition to estimates of the probability of default, we need estimates of recovery rates for defaulted bonds. The estimates available for recovery rates by rating class are computed as a function of the rating at time of issuance. Table $\mathrm{V}$ shows these recovery rates. Thus of necessity we assume the same recovery rate independent of the maturity of the bond and that the recovery rate of a bond currently ranked AA is the same as a newly issued AA bond.

Employing equation (6) along with the default rates from Table IV, the recovery rates 
from Table V, and the coupon rates estimated as explained earlier allows us to calculate the forward rates assuming risk neutrality and zero taxes. This is then converted to an estimate of the spot spread due to expected default under the same assumptions.

Table VI shows the zero tax spread due to expected default under risk neutral valuation. The first characteristic to note is the size of the tax-free spread due to expected default relative to the empirical corporate spread discussed earlier. The zero tax spread from expected default is very small and does not account for much of the corporate spread. This can be seen graphically in Figure 2 for A rated industrial bonds. One factor that could cause us to underestimate the spread due to expected default is that our transition matrix estimates are not calculated over exactly the same period for which we estimate the spreads. However, there are three factors that make us believe that we have not underestimated default spreads. First, our default estimates shown in Table IV are higher than those estimated in other studies. Second, the average default probabilities over the period where the transition matrix is estimated by Moody's and S\&P are close to the average default probabilities in the period we estimate spreads (albeit default probabilities in the latter period are somewhat higher). Third, the S\&P transition matrix which was estimated in a period with higher average default probability and more closely matches the years in which we estimate spread results in lower estimates of defaults. However, as a further check on the effect of default rates on spreads, we calculated the standard deviation of year-toyear default rates over the 20 years ending 1996 . We then increased the mean default rate by two standard deviations. This resulted in a maximum increase in spread for AA's of $.004 \%$ and 
$.023 \%$ for BBB's. Thus, even with extreme default rates, premiums due to expected losses are too small to account for the observed spreads. It also suggest that changes in premiums due to expected loss over time are too small to account for any significant part of the change in spreads over time.

Also note from Table VI the zero tax risk spread due to default loss of AA's relative to BBB's. While the spread for BBB's is higher, the difference in spreads because of differences in default experience is much less than the differences in the empirical corporate spreads.

Differences in default rates cannot explain the differences in spreads between bonds of various rating classes. This strongly suggests that differences in spreads must be explained by other influences, such as taxes or risk premiums. The second characteristic of spreads due to expected default loss to note is the pattern of spreads as the maturity of the spot rate increases. The spread increases for longer maturity spots. This is the same pattern we observe for the empirical spreads shown in Table I. However, for AA and A the increase in premiums due to expected default loss with maturity is less than the increase in the empirical corporate spread.

\section{TAX SPREADS}

Another difference between government bonds and corporate bonds is that the interest payments on corporate bonds are subject to state tax with maximum marginal rates generally between five and ten percent. Since state tax is deductible from income for the purpose of 
federal tax, the burden of state tax is reduced by the federal tax rate. Nevertheless, state taxes could be a major contributor to the spreads. For example, if the coupon was $10 \%$ and effective state taxes were $5 \%$, state taxes alone would result in a $1 / 2 \%$ spread $(.05 \times .10)$. To analyze the impact of state taxes on spreads, we introduced taxes into the analysis developed in the prior section. For a one-period bond maturing at $\$ 1$, the basic valuation equation after state taxes is:

$V_{01}=\left[C\left(1-P_{1}\right)\left(1-t_{s}\left(1-t_{g}\right)\right)+a P_{1}+(1-a) P_{1}\left(t_{s}\left(1-t_{g}\right)\right)+\left(1-P_{1}\right)\right] e^{-r_{01}^{G}}$

where

1. $r_{01}^{G}$ is the government forward rate (which is the spot rate in Period 1).

2. $t_{s}$ is the state tax rate

3. $t_{g}$ is the federal tax rate

other terms are as before.

Equation (7) has two terms that differ from the prior section. The change in the first term represents the payment of taxes on the coupon. The new third term is the tax refund due to a capital loss if the bond defaults.

The valuation equation on promised cash flows is

$V_{01}=[C+1] e^{-r_{01}^{C}}$ 
Equating the two expression for $V_{01}$ and solving for the difference between corporate and government rates, we have

$$
e^{-\left(r_{01}^{C}-r_{01}^{G}\right)}=\left(1-P_{1}\right)+\frac{a P_{1}}{1+C}-\frac{\left[C\left(1-P_{1}\right)-(1-a) P_{1}\right]}{1+C}\left(t_{s}\right)\left(1-t_{g}\right)
$$

The first two terms are identical to the terms shown before where only default risk is taken into account. The last term is the new term that captures the effect of taxes. Taxes enter it in two ways. First, the coupon is taxable and its value is reduced by taxes and is paid with probability $\left(1-\mathrm{P}_{1}\right)$. Second, if the firm defaults (with probability $\mathrm{P}_{1}$ ), the amount lost in default is a capital loss and taxes are recovered. Note that since state taxes are a deduction against federal taxes, the marginal impact of state taxes is $t_{s}\left(1-t_{g}\right)$.

As in the prior section, these equations can be generalized to the $\mathrm{T}$ period case. The final equation is

$$
\left(1-P_{t+1}\right)+\frac{a P_{t+1}}{C+V_{t+1 T}}-\frac{\left.\left[C\left(1-P_{t+1}\right)-(1-a) P_{t+1}\right)\right]}{C+V_{t+1 T}} t_{s}\left(1-t_{g}\right)=e^{-\left(r_{t+1}^{C}-r_{t+1}^{G}\right)}
$$

This equation is used to estimate the forward rate spread because of loss due to expected default and taxes.

The inputs were determined as follows: The coupon was set so that a ten-year bond would 
sell at par. ${ }^{20}$ The same probabilities of default and recovery rates were used as were used when we calculated the premium due to expected default in the last section. Table IV gives the default probabilities as a function of time, and Table $\mathrm{V}$ the recovery rates. State taxes and federal taxes are more difficult to estimate. We used three procedures. First we looked at state tax codes. For most states, maximum marginal state tax rates range between $5 \%$ and $10 \% .{ }^{21}$ Since the marginal tax rate used to price bonds should be a weighted average of the active traders, we assumed that a maximum marginal tax rate would be approximately the mid-point of the range of maximum state taxes, or $7.5 \%$. In almost all states, state tax for financial institutions (the main holder of bonds) is paid on income subject to federal tax. Thus, if interest is subject to maximum state rates, it must also be subject to maximum federal tax, and we assume the maximum federal tax rate of $35 \% .^{22}$

Our second attempt at estimating taxes was to directly determine the effective tax rate (state tax rate adjusted for a federal rate) that best explained market prices. We examined eleven different values of effective tax rates ranging from $0 \%$ to $10 \%$ in steps of one percent. For each tax rate, we estimated the after tax cash flow for every bond in every month in our sample. This was done using cash flows as defined in the multi-period version of equation (7). Then for each

20 We tried alternative coupons. The spread is reasonably insensitive to changes in the coupon and none of the discussion would change with reasonable variations in the coupon.

$21 \quad$ See Commerce Clearing House (1997)

22 For smaller institutions it is $34 \%$. 
month, rating class and tax rate we estimated the spot rates using the Nelson Siegal procedure discussed in section II-B, but now applied to after tax expected cash flows. These spot yield curves are then applied to the appropriate after tax expected cash flows to price all bonds in each rating class in each month. The difference between this computed price and the actual price is calculated for each tax rate. The tax rate which resulted in the smallest mean square error between calculated price and actual price is determined. When we do so, we find that an effective tax rate of $4 \%$ results in the smallest mean squared pricing error. In addition, the $4 \%$ rate produced errors that were significantly lower (at the five percent significance level) than any other rate except $3 \%$. Since the errors were lower on average with the $4 \%$ rate we employ this rate for later analysis. ${ }^{23}$ For the first two estimates of effective taxes, we obtain corporate spreads shown in panel A and B of Table VII. In doing so we convert the forward rates determined from equation (9) to spot rates. Note first that the spreads are less than those found empirically as shown in Table I and that for our best estimate of effective state taxes (4\%), state taxes are more important than expected default in explaining spreads. Recall that increasing default probabilities by two standard deviations only increased the spread for AA bonds by $.003 \%$. Thus increasing defaults to an extreme historical level and, on top of that, allowing the maximum or estimated tax rates is insufficient to explain the corporate spreads found empirically.

However, there is a fair amount of uncertainty as to the appropriate tax rates. Thus we employed one final procedure to try to see if tax rates and default risk are together sufficient to

23 One other estimate in the literature that we are aware of is that produced by Severen and Stewart (1992) who estimate state taxes at 5\%. 
explain spreads. Since AA bonds have the lowest default probabilities in our sample, we would expect the risk premium on these bonds to be smaller than the risk premium on lower rated bonds. If we assume that the risk premium on these bonds is zero, we can get an estimate of the tax rate that is necessary to explain AA spreads. The effective state tax rate needed to explain AA spreads is $6.7 \%$. There are many combinations of federal and state taxes that are consistent with this number. However, as noted above, since state tax is paid on federal income, it is illogical to assume a high state rate without a corresponding high federal rate. Thus the only pair of rates that would explain spreads on AA's is a state tax rate of $10.3 \%$ and a federal rate of $35 \%$. There are very few states with a $10 \%$ rate. Thus, it is hard to explain spreads on AA bonds with taxes and default rates.

Furthermore, we see no reason why the tax factor should differ for AA or BBB bonds. We can apply the tax factor of $6.7 \%$ (that completely explains AA spread) to A and BBB rated bonds. When we do so, we get the estimated spreads shown in Table VII, Panel C. Note that the rates determined by using the risk neutral valuation model on expected values and the tax rates that explain the spreads on AA debt underestimate the spreads on A and BBB bonds. Taxes, default rates, and whatever risk premium that is inherent in AA bonds underestimate the corporate spread on lower rated bonds. Furthermore, as shown in Table VII, Panel C, the amount of the underestimation goes up as the quality of the bonds examined goes down. The inability of tax and default rates to explain the corporate spread for AAs even at extreme tax rates, and the inability to explain the difference in spreads between AA's and BBB's suggest a non zero risk 
premium.

Figure II shows the premium due to expected default loss and tax premium for A rated industrials where the tax premium is based on our best estimate of effective state taxes (4\%). Note, once again, that using our best estimate of effective state tax rate that state taxes are more important than the default premium in explaining spreads. State taxes have been ignored in almost all modeling of the spread (see Jarrow, Lando and Turnbull (1997), Das and Tufano (1996) and Duffee (1998)). Our results indicate that state taxes should be an important influence that should be included in such models if they are to help us understand the causes of corporate bond spreads.

\section{RISK PREMIUMS}

As shown in the last section, premiums due to expected default and state tax rates are insufficient to explain the spread in corporate bonds. Thus, we need to examine the risk premium. There are two issues that need to be addressed. What causes a risk premium and, given the small size of the expected default loss, why the risk premium is so large. ${ }^{24}$

24 An alternative possibility to that discussed shortly is that we might expect a large risk premium because of low probability of default for the following reasons. Bankruptcies tend to cluster in time and institutions are highly levered, so that even with low average bankruptcy losses, there is still a significant chance of 
If corporate bond returns move systematically with other assets in the market while government bonds do not, then corporate bond expected returns would require a risk premium to compensate for the non-diversifiability of corporate bond risk, just like any other asset. The literature of Financial Economics provides evidence that government bond returns are not sensitive to the influences driving stock returns. ${ }^{25}$ There are two reasons why changes in corporate spreads might be systematic. First, if expected default loss were to move with equity prices, so as stock prices rise default risk goes down and as they fall it goes up, it would introduce a systematic factor. Second, the compensation for risk required in capital markets might change over time. If changes in the required compensation for risk affects both corporate bond and stock markets, then this would introduce a systematic influence. We shall now demonstrate that such a relationship exists and that it explains most of the risk premium. We shall do so by relating unexplained spreads (corporate spreads less both the premium for expected default and the tax premium as determined from equation (9)) to variables which have been used as systematic risk factors in the pricing of common stocks. By studying the sensitivity to these risk factors we can estimate the size of the premium required and see if it explains the remaining part of the spread. Throughout we will assume a $4 \%$ effective state tax rate which is our estimate from the prior section

financial difficulty at an uncertain time in the future and we need a premium to compensate for this risk. Even if the institutional bankruptcy risk is small, the consequences of an individual issue bankruptcy on a manager's career may be so significant as to induce decision makers to require a substantial premium.

25 See, for example, Elton (1999) 
In order to examine the impact of sensitivities on unexplained spreads we need to specify a return generating model.

We can write a general return generating model as

$R_{t}=a+\sum_{j} \beta_{j} f_{j t}+e_{t}$

for each year (two through ten) and each rating class

Where

1. $R_{t}$ is the return during month $\mathrm{t}$.

2. $\quad \beta_{j}$ is the sensitivity of changes in the spread to factor $j$.

3. $f_{j t}$ is return on factor $\mathrm{j}$ during month $\mathrm{t}$. The factors are each formulated as the difference in return between two portfolios (zero net investment portfolios).

While this process holds for returns, we want to relate it to the metric that we are investigating, the unexplained spread. Let $r_{t, m}^{c}$ and $r_{t, m}^{G}$ be the spot rates on corporate and government bonds that mature $\mathrm{m}$ periods later respectively. Then the price of a pure discount bond with face value equal to one dollar is

$$
P_{t, m}^{c}=e^{-r_{t, m}^{c} \cdot m}
$$




$$
P_{t, m}^{G}=e^{-r_{t, m}^{G} \cdot m}
$$

and one month later the price of an m period corporate and government bonds are

$$
\begin{aligned}
& P_{t+1, m}^{c}=e^{-r_{t+1, m}^{c} \cdot m} \\
& P_{t+1, m}^{G}=e^{-r_{t+1, m}^{G} \cdot m}
\end{aligned}
$$

That part of the return on an $m$ period zero coupon bond from $t$ to $t+1$ due to a change in spread is $^{26}$

$$
R_{t, t+1}^{c}=\ln \frac{e^{-r_{t+1, m}^{c} \cdot m}}{e^{-r_{t, m}^{c} \cdot m}}=m\left(r_{t, m}^{c}-r_{t+1, m}^{c}\right)
$$

and

$$
R_{t, t+1}^{G}=\ln \frac{e^{-r_{t+1, m}^{G} \cdot m}}{e^{-r_{t, m}^{G} \cdot m}}=m\left(r_{t, m}^{G}-r_{t+1, m}^{G}\right)
$$

and

$$
R_{t, t+1}^{c}-R_{t, t+1}^{G}=-m\left[\left(r_{t+1, m}^{c}-r_{t+1, m}^{G}\right)-\left(r_{t, m}^{c}-r_{t, m}^{G}\right)\right]=-m \Delta S_{t, m}
$$

Where $\Delta S_{t, m}$ is the change in spread from time $t$ to $t+1$ on a $m$ period bond. Thus the

26 This is not the total return on holding a corporate or government bond, but rather the portion of the return due to changing spread (the term we wish to examine). 
difference in return between corporate and government bonds due to a change in spread is equal to minus $\mathrm{m}$ times the change in spread.

Recognize that we are interested in the unexplained spread which is the difference between the corporate government spread and that part of the spread which is explained by expected default loss and taxes. We can write the unexplained differential in returns where the superscript has been added to note that we are dealing with that part of the spread on corporate bonds that is not explained by expected default loss and taxes as:

$$
R_{t, t+1}^{u c}-R_{t, t+1}^{G}=-m\left[\left(r_{t+1, m}^{u c}-r_{t+1, m}^{G}\right)-\left(r_{t, m}^{u c}-r_{t, m}^{G}\right)\right]=-m \Delta S_{t, m}^{u}
$$

There are many forms of a multi-index model which we could employ to study unexplained spreads. We chose to concentrate our results on the Fama-French 3-factor model because of its wide use in the literature but we also investigated other models including the single index model and some of the results will be discussed in footnotes. ${ }^{27}$ The Fama-French model employs the excess return on the market, the return on a portfolio of small stocks minus the

27 We used two multi-factor models, the Connor Korajczyk (1993) empirically derived model and the multi-factor model tested by us earlier see Elton, Gruber and Blake (1998). These results will be discussed in footnotes. We thank Bob Korajczyk for supplying us with the monthly returns on the Connor Korajczyk factors. 
return on a portfolio of large stocks (the SMB factor) and the return on a portfolio of high minus low book to market stocks (the HML factor) as its three factors.

Table VIII shows the results of regressing return of corporates over governments derived from the change in unexplained spread for industrial bonds (as in equation (12)) against the Fama French factors. ${ }^{28}$ The regression coefficient on the market factor is always positive and is statistically significant 20 out of 27 times. This is the sign we would expect on the basis of theory. This holds for the Fama French market factor, and also holds (see Table VIII) for the other Fama French factors representing size and book to market ratios. The return is positively related to the SMB factor and to the HML factor. ${ }^{29}$ Notice that the sensitivity to all of these factors tends to increase as maturity increases and to increase as quality decreases. This is exactly what would be expected if we were indeed measuring risk factors. Examining financials shows similar results except that the statistical significance of the regression coefficients and the size of the $R^{2}$ is higher for AA's.

It appears that the change in spread not related to taxes or expected defaults is at least in

28 If we find no systematic influences it does not imply that the unexplained returns are not risk premiums due to systematic influences. It may simply mean that we have failed to uncover the correct systematic influences. However, finding a relationship is evidence that the unexplained returns are due to a risk premium

29 The results are almost identical using the Connor Korajczyk empirically derived factors or the Elton, Gruber and Blake (1998) model. When a single factor model is used, 20 out of 27 betas are significant with an $\mathrm{R}^{2}$ of about 0.10 . 
part explained by factors which have been successful in explaining changes in returns over time in the equity market. We will now turn to examining cross sectional differences in average unexplained premiums. If there is a risk premium for sensitivity to stock market factors unexplained premium should be linearly related to the sensitivities of the unexplained premiums (the $\beta$ 's from equation (12)) and differences in sensitivities should explain differences in the unexplained premium across corporate bonds of different maturity and different rating class. We have 27 unexplained spreads for industrial bonds and 27 for financial bonds since maturities range from 2 years, through 10 years, and there are three rating classifications. When we regress the average unexplained spread against sensitivities for industrial bonds the cross sectional $R^{2}$ adjusted for degrees of freedom is .32 , while for financials it is .58 . We have been able to account for almost $1 / 3$ of the difference in unexplained premiums for industrials and more than $1 / 2$ for financial bonds. ${ }^{30}$

Another way to examine this is to ask how much of the unexplained spread can the sensitivities account for. That is for each maturity and risk class of bonds what is the size of the unexplained spread that existed versus the size of the risk premium that is accounted for by the sensitivity of the bonds to the three factors times the price of these factors over the time period. For industrials the average risk premium is .813 , while just employing the sensitivities we would estimate it to be .660 . For financial, the actual risk premium is .934 but using the estimated beta

30 Employing a single index model using sensitivity to the excess return on the S\&P index, leads to $R^{2}$ of .21 and .43 for industrial and financial bonds respectively.. 
and prices it is .605 . In short, $85 \%$ of the industrial unexplained spread is accounted by the three risk sensitivities while for financials it is $67 \%$. Note that whether we use the cross sectional explanatory power or the size of the estimate relative to the realized risk premium we see that standard risk measures have been able to account for a high percentage of the unexplained spread.

We tried one more set of tests. One possible explanation for our results is that the Fama French factors are proxying for changes in default expectations. If this is the case, in cross section, the sensitivity of unexplained spreads to the factors may in part be picking up the market price of systematic changes in default expectations. To test this we added several measures of changes in default risk to equation (10) as a fourth factor. We tried actual changes (perfect forecasting) and several distributed lag and lead models. None of the results were statistically significant or had consistent signs across different groups of bonds.

In this section we have shown that the change in unexplained spread is related to factors that are considered systematic in the stock market. Modern risk theory states that systematic risk needs to be compensated for and thus, common equity has to earn a risk premium. Changes in corporate spreads lead to changes in return on corporates and thus, returns on corporates are also systematically related to common stock factors with the same sign as common equity. If common equity receives a risk premium for this systematic risk then corporate bonds must also earn a risk premium. We have shown that sensitivity to the factors that are used to explain risk premiums in 
common stocks explain between $1 / 3$ and $1 / 2$ of the spread in corporate and government rates that is not explained by the difference between promised and expected payments and taxes. This is strong evidence of the existence of a risk premium of a magnitude that has economic significance and provides an explanation as to why the risk premium is so large. 


\section{CONCLUSION}

In this paper, we have examined the size and cause of differences in spot rates on corporate bonds relative to government bonds. We have discussed the methodology for arriving at, and the results from looking at, corporate spot spreads. The properties of the corporate spot spread are useful in examining the reasonableness of alternative corporate bond valuation models derived from option pricing. We then examine the three components of the corporate spot spread: the premium due to expected default, a tax premium, and the unexplained portion. We show that the premium due to expected loss is quite small compared to the overall corporate spread. Differential taxes, on the other hand, can potentially be a major factor in accounting for the overall corporate spread. Finally, of key significance, our results indicate that a large part of the remainder of the spread appears to be a risk premium in the pricing of corporate debt. We show that part of the corporate spread not explained by expected loss or taxes has a strong relationship to priced systematic risk factors which have been found to account for differences in expected stock returns. Furthermore, differences in the size of the unexplained spread is related to differences in the sensitivity to the systematic factors.

There has been a lot of modeling in the corporate bond area. One of the purposes of this paper is to provide empirical facts and estimates of the magnitude of influences that a model should reflect in order to explain what determines actual spreads. In particular, we show that state taxes explain part of the spread and that the risk premium is partially a compensation for 
systematic components in the financial markets and not just compensation for increased default risk. Models such as Jarrow, Lando and Turnbull(1997) and its descendants which explain prices in terms of risk adjusted probabilities have not yet been able to decompose returns into components due to expected loss, taxes, and risk premiums. To price debt instruments with different risk or tax implications one has to know the sources and magnitude of the influences which effect bond prices. The decompositions are necessary for a rational choice by investors facing different taxes and having different degrees of risk aversion. 


\section{REFERENCES}

Altman, Edward, 1997, Rating migration of corporate bonds: Comparative results and investor/lender implications, NYU Salomon Center Working Paper Series S-97-3.

Altman, Edward, 1989, Measuring corporate bond mortality and performance, Journal of Finance 44, 909-922.

Altman, Edward and Kishore Vellore, 1998, Defaults and returns on high yield bonds: Analysis through 1997. NYU Salomon Center Working Paper Series S-98-1.

Black, F. and M. Scholes, 1983, The pricing of options and corporate liabilities, Journal of Political Economy 81, 399-418.

Blume, M. E., D.B. Keim and S.A. Patel, 1991, Returns and the volatility of low grade bonds, Journal of Finance 46, 49-74.

Bodie, Zvi, Kane, Alex, and Marcus, Alan, 1993, Investments, Irwin, Homewood, Illinois.

Brown, K., W. Harlow and D. Smith, 1993, An empirical analysis of interest rate swap spreads, Journal of Fixed Income, 3 March, 61-78.

Cathcart, L. and L. El-Jahel, 1998, Valuation of defaultable bonds, Journal of Fixed Income, 8, 65-78.

Carty, L. and J. Fons, 1994, Measuring changes in credit quality, Journal of Fixed Income 4, 27 41.

Chen, N., R. Roll and S. Ross, 1986, Economic factors and the stock market,. Journal of Business 59, 383-403.

Commerce Clearing House, 1997. State Tax Handbook. Commerce Clearing House, Inc., Chicago, IL.

Connor, G. and R.A. Korajczyk, 1993, "A test for the Number of Factors in an Approximate Factor Model, Journal of Finance, 48(4), 1263-91

Cornell, B. and R. Green, 1991, Returns and volatility of low-grade bonds, 1977-1989, Journal of Finance 46, 29-48.

Cox, John, Indgersoll, John, and Ross, Steve, 1985, “A Theory of the Term Structure of Interest Rates," Econometrica, vol 53, pgs. 385-408 
Cumby, Bob and Martin Evans, 1995, The term structure of credit risk: estimates and specification tests, Department of Economics, Georgetown University.

Dahlquist, M. and L.E.O. Svensson. 1996, "Estimating the Term Structure of Interest Rates for Monetary Policy Analysis,” Scadinavian Journal of Economics, 98(2), 163-83

Das, Sanjiv R. and Peter Tufano, 1996, "Pricing Credit Sensitive Debt When Interest Rates, Credit Ratings and Credit Spreads are Stochastic," Journal of Financial Engineering, vol 5, 161-198.

Duffee, G., 1998, "The Relation Between Treasury Yields and Corporate Bond Yield Spreads," Journal of Finance, vol 53, No 6, pgs 2225-2240.

Duffie, D. and M. Huang, 1994, Swap rates and credit quality, Working Paper, Graduate School of Business, Stanford University.

Duffie, D. and K. Singleton, 1997, Modeling term structures of defaultable bonds, Graduate School of Business, Stanford University.

Elton, Edwin J, "Expected Return, Realized Return and Asset Pricing Tests," Journal of Finance, Vol. 54, No 4, pgs 1199-1221.

Elton, Edwin, and T. Clifton Green, 1998, "Tax and Liquidity Effects in Pricing Government Bonds," Journal of Finance, vol 53, No.5, pgs. 1533-1562.

Elton, E., M. Gruber and Blake, C., 1998, Common factors in mutual fund returns, Forthcoming, European Finance Review.

Elton, Edwin J., M. Gruber and R. Michaely, 1990, “The Structure of Spot Rates and Immunization," Journal of Finance.

Fama, E.F., 1986, Term premiums and default premiums in money markets, Journal of Financial Economics 17, 175-196.

Fama, E. and K. French, 1993, Common risk factors in the returns on stocks and bonds, Journal of Financial Economics 33, 3-57.

Fisher, L., 1959, Determinants of risk premiums on corporate bonds, Journal of Political Economy 67, 217-237.

Fons, Jerome S., 1994, Using default rates to model the term structure of credit risk, Financial 
Analysts Journal 50, 25-32.

Geske, R., 1977, The valuation of corporate liabilities as compound options, Journal of Financial and Quantitative Analysis 12, 541-552.

Goodman, L.S., 1989, High yield default rates: is there cause for concern?, Goldman, Sachs \& Co., Fixed Income Research, New York.

Green, C. and A. Odegaard, 1997, Tax effects in relative pricing of U.S. government bonds, Journal of Finance 52, 2, 609-633.

Helwege, J. and P. Kleinan, 1997, Understanding aggregate default rates of high yield bonds, Journal of Fixed Income 7, 55-61.

Helwege, J. and C. Turner, 1996, The slope of the credit yield curve for speculative grade issues, Unpublished working paper, Federal Reserve Bank of New York.

Jarrow, R. A. Lando, and S. Turnbull, 1994, A Markov model for the term structure of credit spreads, Review Of Financial Studies, vol 10 pp 481-523.

Johnson, R., 1967, Term structure of corporate bonds yields as a function of risk of default, Journal of Finance 22, 313-345.

Kim, I., K. Ramaswamy and S. Sundaresan, 1987,. The valuation of corporate fixed income securities,. Manuscript, Columbia University.

Lando, D., 1994, On Cox processes and credit risky bonds, Working paper, Institute of Mathematical Statistics, University of Copenhagen, Denmark.

Litterman, R. and J. Scheinkman, 1991, Common factors affecting bond returns, Journal of Fixed Income 1, 54-61.

Litzenberger, H. and Rolfo, 1984, An international study of tax effects on government bond prices, Journal of Finance 39, 1-22.

Longstaff, F.A. and E.S. Schwartz, 1995, A simple approach to valuing risky fixed and floating rate debt, Journal of Finance 50, 789-819.

Madan, D. B. and H. Unal, 1994, Pricing the risks of default, Working paper, Wharton School, University of Pennsylvania.

Mason, S.P. and S. Bhattacharya, 1981, Risky debt, jump process, and safety covenants, Journal 
of Financial Economics 9, 281-307.

McCulloch, J., 1971, "Measuring the Term Structure of Interest Rates," Journal of Business, 44, 19-31.

Merton, R.C., 1974, On the pricing of corporate debt: the risk structure of interest rates, Journal of Finance 29, 449-470.

Moodys Investors Service, 1998, Historical default rates of corporate bond issuers 1920-1997.

Nelson, R. and F. Siegel, 1987, Parsimonious modeling of yield curves, Journal of Business 60, 473-489.

Nielsen, L. J. Saá-Requejo, and P. Santa-Clara, 1993, Default risk and interest rate risk: the term structure of default spreads, Working Paper, INSEAD, Fontainebleau, France.

Pitts, C.G.C. and M.J.P. Selby, 1983, The pricing of corporate debt: a further note, Journal of Finance 38, 1311-1313.

Sarig, O. and A. Warga, 1989, Bond price data and bond market liquidity, Journal of Financial and Quantitative Analysis 24, 367-378.

Sarig, O. and A. Warga, 1989, Some empirical estimates of the risk structure of interest rates, Journal of Finance 44, 1351-1360.

Severn, A. K. and W. J. Stewart, 1992, The corporate-Treasury yield spread and state taxes, Journal of Economics and Business 44, 161-166.

Warga, A., 1998, Fixed income data base, University of Houston, Houston, Texas

Wei, D. G. and G. Dajiang, 1997, Pricing risky debt: an empirical comparison of the Longstaff and Schwartz and Merton models, Journal of Fixed Income 7, 8-28. 


\section{EFFECT OF CHANGES IN THE TREASURY SPOT CURVE ON CORPORATE}

\section{SPREADS}

[this section, included in Draft 7, was not returned with edits]

In this section we examine what happens to corporate spreads as the level and shape of the Treasury (riskless) spot curve changes. While the relationship of corporate spread calculated as differences in yield to maturity has been examined with respect to changes in the level and slope of the Treasury yield curve, this is the first paper to examine it when corporate spread is calculated using differences in spot rates.

In Table the results are reported for industrial bonds from regressing the change in the spot corporate spread for each maturity against changes in the level and steepness of the Treasury spot curve. In the regression level was measured by the spot rate for two-year Treasuries and steepness by the difference between the spot rate for ten-year Treasuries and two-year Treasuries. $^{31}$

The surprising results from this table are how much of the change in risk spread is explained by changes in the steepness and level of the U.S. Treasuries spot curve. Most of this is due to changes in the steepness of the U.S. Treasury spot curve. For spots at or above six years, examining a univariate regression with only steepness (not shown) shows that over $50 \%$ of the change in corporate spreads are explained by changes in the steepness of the government spot

31 The results for financials are substantially the same and are not reported in the interest of brevity. 
curve. Examining the $\mathrm{t}$ values and $\mathrm{R}^{2}$ from Table shows that for corporate spreads of three years or more, almost all of the explanatory power is associated with changes in the Treasury curve. The relationship is positive, indicating that when the spread between long-term spots and short-term spots increases the corporate spreads between any category of risky debt and Treasuries goes up. The different between long government rates and short government rates has frequently been used as a risk measure. To the extent that the steepness of the government spot curve reflects risk and uncertainty, it is logical that it is highly correlated with corporate risk spreads.

Table also demonstrates that changes in the corporate spreads of corporates are negatively correlated with the change in the level of short-term Treasury spots. While this relationship is highly persistent across all risk classes and maturities, it is rarely statistically significant and this variable as a stand-alone explanation has very weak explanatory power except for the risk spread for two- and three-year spots. It does appear that as short-term Treasury spots go up, there is a small tendency for corporate spreads to narrow. 


\section{THE APPLICABILITY OF SPOT RATES TO PROMISED PAYMENTS}

Up to now we have studied a set of spot (or future) rates that are consistent with the pricing of risky debt. In this section of the paper we show that solving for these spot rates and/or associated discount functions to price risky debt is at best a close approximation to the way such debt should be priced in the market. We will do so by first considering the pricing of debt in a risk-neutral world. Later we will attempt to see if the debt markets exhibit risk avoidance. ${ }^{32}$

The use of spot rates to price government bonds is justified by the law of one price. Identical certain cash flows in the future must have the same present value and so be discounted at the same rate. In a risk-neutral world, the same pricing principal must apply to expected cash flows.

In the simple example which follows, we show that in general a portfolio which has the same expected cash flows as a second portfolio will not have the same promised cash flows. For simplicity, consider three bonds. Bond A is a two-period coupon bond, bond B a one-period pure discount bond, and bond $\mathrm{C}$ a two-period pure discount bond. Assume they all have the same promised coupon $(\mathrm{C})$ and that the probability of failing in any period is the same, denoted by $\mathrm{P}$, and the par value is $\$ 1$.

32 Some authors (to be added) have argued that risk avoidance does not exist in the corporate bond market and differences between expected and promised cash flows account for all of the difference in the price of corporate and government debt. 
The expected cash flows from the bonds are given in the table below:

\section{Period 1}

Bond A

Bond B

Bond C
$\mathrm{C}(1-\mathrm{P})+\mathrm{Pa}$

$\mathrm{C}(1-\mathrm{P})+\mathrm{Pa}+(1-\mathrm{P})$

$\mathrm{Pa}$

\section{Period 2}

$\mathrm{C}(1-\mathrm{P})^{2}+\mathrm{Pa}(1-\mathrm{P})+(1-\mathrm{P})^{2}$

$C(1-P)^{2}+P a(1-P)+(1-P)^{2}$

Identical expected cash flows in Period 2 are obtained by holding one unit of Bond A and one unit of Bond C. To match the expected cash flow from Bond A in Period 1, given that we hold one unit of Bond $\mathrm{C}$, enough of Bond B must be held to generate a cash flow $\mathrm{C}(1-\mathrm{P})$. This means that $\frac{C}{1+C+\frac{P a}{1-P}}$ units of Bond B must be held. In a risk-neutral world, since these

portfolios have the same expected cash flow, each period, they must sell at the same price and each period a single discount rate is appropriate for arriving at the price.

If we examine the promised cash flow on these bonds, we get a different result:

\section{PROMISED CASH FLOW}

Period 1

Bond A

Period 2
C
$\mathrm{C}+1$ 
Bond B $\quad \mathrm{C}+1$

Bond $\mathrm{C} \quad \mathrm{C}+1$

While holding one unit of bond $\mathrm{C}$ matches the cash flow of bond A in Period 2,

holding $\frac{c}{1+c+\frac{P a}{1-P}}$ of bond B plus bond $\mathrm{C}$ does not cause promised cash flows to be matched in

period 1. To match promised cash flows, we should hold $\frac{C}{1+C}$ units of Bond B. While the

correct discount rate to use on expected cash flows is purely a function of time, the correct discount rate to use for promised payments is not independent of the pattern of payments and thus is not simply based on time. This means the estimation of spot rates on promised cash flows is an approximation. 
Table I

\section{Measured Spread From Treasury}

This table reports the average spread from treasuries for AA, A, and BBB bonds in the financial and industrial sectors. For each column, spot rates were derived using standard Gauss-Newton non-linear least squared methods as described in the text. Treasuries are reported as annualized spot rates. Corporates are reported as the difference between the derived corporate spot rates and the derived treasury spot rates. The financial sector and the industrial sector are defined by the bonds contained in the Lehman Brother's financial index and industrial index respectively. Panel A contains the average spot rates and spreads over the entire ten year period. Panel B contains the averages for the first five years and panel C contains the averages for the final five years.

\begin{tabular}{ccccccccc}
\hline & Treasuries & \multicolumn{3}{c}{ Financial Sector } & \multicolumn{3}{c}{ Industrial Sector } \\
\hline Maturity & & AA & A & BBB & AA & A & BBB \\
\hline & Panel A: $1987-1996$ & & & & & & \\
\hline 2 & 6.414 & 0.586 & 0.745 & 1.199 & 0.414 & 0.621 & 1.167 \\
3 & 6.689 & 0.606 & 0.791 & 1.221 & 0.419 & 0.680 & 1.205 \\
4 & 6.925 & 0.624 & 0.837 & 1.249 & 0.455 & 0.715 & 1.210 \\
5 & 7.108 & 0.637 & 0.874 & 1.274 & 0.493 & 0.738 & 1.205 \\
6 & 7.246 & 0.647 & 0.902 & 1.293 & 0.526 & 0.753 & 1.199 \\
7 & 7.351 & 0.655 & 0.924 & 1.308 & 0.552 & 0.764 & 1.193 \\
8 & 7.432 & 0.661 & 0.941 & 1.320 & 0.573 & 0.773 & 1.188 \\
9 & 7.496 & 0.666 & 0.955 & 1.330 & 0.589 & 0.779 & 1.184 \\
10 & 7.548 & 0.669 & 0.965 & 1.337 & & 0.603 & 0.785 & 1.180 \\
\hline & Panel B: $1987-1991$ & & & & & & \\
\hline 2 & 7.562 & 0.705 & 0.907 & 1.541 & 0.436 & 0.707 & 1.312 \\
3 & 7.763 & 0.711 & 0.943 & 1.543 & 0.441 & 0.780 & 1.339 \\
4 & 7.934 & 0.736 & 0.997 & 1.570 & 0.504 & 0.824 & 1.347 \\
5 & 8.066 & 0.762 & 1.047 & 1.599 & 0.572 & 0.853 & 1.349 \\
6 & 8.165 & 0.783 & 1.086 & 1.624 & 0.629 & 0.872 & 1.348 \\
7 & 8.241 & 0.800 & 1.118 & 1.644 & 0.675 & 0.886 & 1.347 \\
8 & 8.299 & 0.813 & 1.142 & 1.659 & 0.711 & 0.897 & 1.346 \\
9 & 8.345 & 0.824 & 1.161 & 1.672 & 0.740 & 0.905 & 1.345 \\
10 & 8.382 & 0.833 & 1.177 & 1.682 & 0.764 & 0.912 & 1.344 \\
\hline & Panel C: $1992-1996$ & & & & & & \\
\hline 2 & 5.265 & 0.467 & 0.582 & 0.857 & 0.392 & 0.536 & 1.022 \\
3 & 5.616 & 0.501 & 0.640 & 0.899 & 0.396 & 0.580 & 1.070 \\
4 & 5.916 & 0.511 & 0.676 & 0.928 & 0.406 & 0.606 & 1.072 \\
5 & 6.150 & 0.512 & 0.701 & 0.948 & 0.415 & 0.623 & 1.062 \\
6 & 6.326 & 0.511 & 0.718 & 0.962 & 0.423 & 0.634 & 1.049 \\
7 & 6.461 & 0.510 & 0.731 & 0.973 & 0.429 & 0.642 & 1.039 \\
8 & 6.565 & 0.508 & 0.740 & 0.981 & 0.434 & 0.649 & 1.030 \\
9 & 6.647 & 0.507 & 0.748 & 0.987 & 0.438 & 0.653 & 1.022 \\
10 & 6.713 & 0.506 & 0.754 & 0.993 & 0.441 & 0.657 & 1.016 \\
\hline
\end{tabular}


Table II

\section{Average Root Mean Squared Errors}

This table contains the average root mean square error of the difference between theoretical price computed from the spot rates derived from the Gauss-Newton procedure and the actual bond invoice prices. For a given class of securities, the root mean squared error is calculated once per period. The number reported is the average of all the root mean squared errors within a class over the period indicated.

\begin{tabular}{lccccccc}
\hline Period & Treasuries & \multicolumn{3}{c}{ Financial Sector } & \multicolumn{3}{c}{ Industrial Sector } \\
\hline & & AA & A & BBB & AA & A & BBB \\
\hline $1987-1996$ & 0.210 & 0.512 & 0.861 & 1.175 & 0.728 & 0.874 & 1.516 \\
$1987-1991$ & 0.185 & 0.514 & 0.996 & 1.243 & 0.728 & 0.948 & 1.480 \\
$1992-1996$ & 0.234 & 0.510 & 0.726 & 1.108 & 0.727 & 0.800 & 1.552 \\
\hline
\end{tabular}




\section{One Year Transition Probability Matrix}

The Panel (A) below is taken from Carty and Fons (1994) and Panel (B) is from S\&P (1995). However, the category in the original references titled Non-Rated (which is primarily bonds that are bought back or issued by companies which merge) has been allocated to the other rating classes so that each row sums to one. Each entry in a row shows the probability that a bond with a rating shown in the first column ends up one year later in the category shown in the column headings.

Panel (A) : Moody's

\begin{tabular}{lrrrrrrrr}
\hline & Aaa & Aa & \multicolumn{1}{c}{ A } & Baa & Ba & B & Caa & Default \\
\hline Aaa & $91.897 \%$ & $7.385 \%$ & $0.718 \%$ & $0.000 \%$ & $0.000 \%$ & $0.000 \%$ & $0.000 \%$ & $0.000 \%$ \\
Aa & $1.131 \%$ & $91.264 \%$ & $7.091 \%$ & $0.308 \%$ & $0.206 \%$ & $0.000 \%$ & $0.000 \%$ & $0.000 \%$ \\
$\mathrm{~A}$ & $0.102 \%$ & $2.561 \%$ & $91.189 \%$ & $5.328 \%$ & $0.615 \%$ & $0.205 \%$ & $0.000 \%$ & $0.000 \%$ \\
$\mathrm{Baa}$ & $0.000 \%$ & $0.206 \%$ & $5.361 \%$ & $87.938 \%$ & $5.464 \%$ & $0.825 \%$ & $0.103 \%$ & $0.103 \%$ \\
$\mathrm{Ba}$ & $0.000 \%$ & $0.106 \%$ & $0.425 \%$ & $4.995 \%$ & $85.122 \%$ & $7.333 \%$ & $0.425 \%$ & $1.594 \%$ \\
$\mathrm{~B}$ & $0.000 \%$ & $0.109 \%$ & $0.109 \%$ & $0.543 \%$ & $5.972 \%$ & $82.193 \%$ & $2.172 \%$ & $8.903 \%$ \\
Caa & $0.000 \%$ & $0.437 \%$ & $0.437 \%$ & $0.873 \%$ & $2.511 \%$ & $5.895 \%$ & $67.795 \%$ & $22.052 \%$ \\
Default & $0.000 \%$ & $0.000 \%$ & $0.000 \%$ & $0.000 \%$ & $0.000 \%$ & $0.000 \%$ & $0.000 \%$ & $100.000 \%$ \\
\hline
\end{tabular}

Panel (B) : Standard and Poor's

\begin{tabular}{lrrrrrrrr}
\hline & AAA & AA & A & BBB & BB & \multicolumn{1}{c}{ B } & CCC & Default \\
\hline AAA & $90.788 \%$ & $8.291 \%$ & $0.716 \%$ & $0.102 \%$ & $0.102 \%$ & $0.000 \%$ & $0.000 \%$ & $0.000 \%$ \\
AA & $0.103 \%$ & $91.219 \%$ & $7.851 \%$ & $0.620 \%$ & $0.103 \%$ & $0.103 \%$ & $0.000 \%$ & $0.000 \%$ \\
A & $0.924 \%$ & $2.361 \%$ & $90.041 \%$ & $5.441 \%$ & $0.719 \%$ & $0.308 \%$ & $0.103 \%$ & $0.103 \%$ \\
BBB & $0.000 \%$ & $0.318 \%$ & $5.938 \%$ & $86.947 \%$ & $5.302 \%$ & $1.166 \%$ & $0.117 \%$ & $0.212 \%$ \\
BB & $0.000 \%$ & $0.110 \%$ & $0.659 \%$ & $7.692 \%$ & $80.549 \%$ & $8.791 \%$ & $0.989 \%$ & $1.209 \%$ \\
B & $0.000 \%$ & $0.114 \%$ & $0.227 \%$ & $0.454 \%$ & $6.470 \%$ & $82.747 \%$ & $4.086 \%$ & $5.902 \%$ \\
CCC & $0.228 \%$ & $0.000 \%$ & $0.228 \%$ & $1.251 \%$ & $2.275 \%$ & $12.856 \%$ & $60.637 \%$ & $22.526 \%$ \\
Default & $0.000 \%$ & $0.000 \%$ & $0.000 \%$ & $0.000 \%$ & $0.000 \%$ & $0.000 \%$ & $0.000 \%$ & $100.000 \%$ \\
\hline
\end{tabular}




\section{Table IV}

\section{Evolution of Default Probability}

Probability of default in year $n$ conditional on (a) a particular starting rating and (b) not having defaulted prior to year $\mathrm{n}$. These are determined using the transition matrix shown in Table IV. Panel (A) is based on Moody's transition matrix of table IV(A) and Panel (B) is based on Standard and Poor's transition matrix of table IV(B).

Panel (A) : Moody's

\begin{tabular}{rccccccc}
\hline year & Aaa & Aa & A & Baa & Ba & B & Caa \\
\hline 1 & $0.000 \%$ & $0.000 \%$ & $0.000 \%$ & $0.103 \%$ & $1.594 \%$ & $8.903 \%$ & $22.052 \%$ \\
2 & $0.000 \%$ & $0.004 \%$ & $0.034 \%$ & $0.274 \%$ & $2.143 \%$ & $8.664 \%$ & $19.906 \%$ \\
3 & $0.001 \%$ & $0.011 \%$ & $0.074 \%$ & $0.441 \%$ & $2.548 \%$ & $8.355 \%$ & $17.683 \%$ \\
4 & $0.002 \%$ & $0.022 \%$ & $0.121 \%$ & $0.598 \%$ & $2.842 \%$ & $8.003 \%$ & $15.489 \%$ \\
5 & $0.004 \%$ & $0.036 \%$ & $0.172 \%$ & $0.743 \%$ & $3.051 \%$ & $7.628 \%$ & $13.421 \%$ \\
6 & $0.008 \%$ & $0.053 \%$ & $0.225 \%$ & $0.874 \%$ & $3.193 \%$ & $7.246 \%$ & $11.554 \%$ \\
7 & $0.013 \%$ & $0.073 \%$ & $0.280 \%$ & $0.991 \%$ & $3.283 \%$ & $6.867 \%$ & $9.927 \%$ \\
8 & $0.019 \%$ & $0.095 \%$ & $0.336 \%$ & $1.095 \%$ & $3.331 \%$ & $6.498 \%$ & $8.553 \%$ \\
9 & $0.027 \%$ & $0.120 \%$ & $0.391 \%$ & $1.185 \%$ & $3.348 \%$ & $6.145 \%$ & $7.416 \%$ \\
10 & $0.036 \%$ & $0.146 \%$ & $0.445 \%$ & $1.264 \%$ & $3.340 \%$ & $5.810 \%$ & $6.491 \%$ \\
11 & $0.047 \%$ & $0.174 \%$ & $0.499 \%$ & $1.331 \%$ & $3.312 \%$ & $5.496 \%$ & $5.743 \%$ \\
12 & $0.060 \%$ & $0.204 \%$ & $0.550 \%$ & $1.387 \%$ & $3.271 \%$ & $5.203 \%$ & $5.141 \%$ \\
13 & $0.074 \%$ & $0.234 \%$ & $0.599 \%$ & $1.435 \%$ & $3.218 \%$ & $4.930 \%$ & $4.654 \%$ \\
14 & $0.089 \%$ & $0.265 \%$ & $0.646 \%$ & $1.474 \%$ & $3.157 \%$ & $4.678 \%$ & $4.258 \%$ \\
15 & $0.106 \%$ & $0.297 \%$ & $0.691 \%$ & $1.506 \%$ & $3.092 \%$ & $4.444 \%$ & $3.932 \%$ \\
16 & $0.124 \%$ & $0.329 \%$ & $0.733 \%$ & $1.532 \%$ & $3.022 \%$ & $4.229 \%$ & $3.662 \%$ \\
17 & $0.143 \%$ & $0.362 \%$ & $0.773 \%$ & $1.552 \%$ & $2.951 \%$ & $4.030 \%$ & $3.435 \%$ \\
18 & $0.163 \%$ & $0.394 \%$ & $0.810 \%$ & $1.567 \%$ & $2.878 \%$ & $3.846 \%$ & $3.241 \%$ \\
19 & $0.184 \%$ & $0.426 \%$ & $0.845 \%$ & $1.578 \%$ & $2.806 \%$ & $3.676 \%$ & $3.074 \%$ \\
20 & $0.206 \%$ & $0.457 \%$ & $0.877 \%$ & $1.585 \%$ & $2.735 \%$ & $3.519 \%$ & $2.928 \%$ \\
\hline
\end{tabular}

Panel (B) : Standard and Poor's

\begin{tabular}{rlcccccc}
\hline year & AAA & AA & A & BBB & BB & B & CCC \\
\hline 1 & $0.000 \%$ & $0.000 \%$ & $0.103 \%$ & $0.212 \%$ & $1.209 \%$ & $5.902 \%$ & $22.526 \%$ \\
2 & $0.002 \%$ & $0.017 \%$ & $0.154 \%$ & $0.350 \%$ & $1.754 \%$ & $6.253 \%$ & $18.649 \%$ \\
3 & $0.007 \%$ & $0.037 \%$ & $0.204 \%$ & $0.493 \%$ & $2.147 \%$ & $6.318 \%$ & $15.171 \%$ \\
4 & $0.013 \%$ & $0.061 \%$ & $0.254 \%$ & $0.632 \%$ & $2.424 \%$ & $6.220 \%$ & $12.285 \%$ \\
5 & $0.022 \%$ & $0.087 \%$ & $0.305 \%$ & $0.761 \%$ & $2.612 \%$ & $6.031 \%$ & $10.031 \%$ \\
6 & $0.032 \%$ & $0.115 \%$ & $0.355 \%$ & $0.879 \%$ & $2.733 \%$ & $5.795 \%$ & $8.339 \%$ \\
7 & $0.045 \%$ & $0.145 \%$ & $0.406 \%$ & $0.983 \%$ & $2.804 \%$ & $5.540 \%$ & $7.095 \%$ \\
8 & $0.059 \%$ & $0.177 \%$ & $0.457 \%$ & $1.075 \%$ & $2.836 \%$ & $5.280 \%$ & $6.182 \%$ \\
9 & $0.075 \%$ & $0.210 \%$ & $0.506 \%$ & $1.153 \%$ & $2.840 \%$ & $5.025 \%$ & $5.506 \%$ \\
10 & $0.093 \%$ & $0.243 \%$ & $0.554 \%$ & $1.221 \%$ & $2.822 \%$ & $4.780 \%$ & $4.993 \%$ \\
11 & $0.112 \%$ & $0.278 \%$ & $0.600 \%$ & $1.277 \%$ & $2.790 \%$ & $4.548 \%$ & $4.594 \%$ \\
12 & $0.132 \%$ & $0.313 \%$ & $0.644 \%$ & $1.325 \%$ & $2.746 \%$ & $4.330 \%$ & $4.272 \%$ \\
13 & $0.154 \%$ & $0.348 \%$ & $0.686 \%$ & $1.363 \%$ & $2.695 \%$ & $4.125 \%$ & $4.006 \%$ \\
14 & $0.176 \%$ & $0.383 \%$ & $0.726 \%$ & $1.395 \%$ & $2.639 \%$ & $3.934 \%$ & $3.780 \%$ \\
15 & $0.200 \%$ & $0.419 \%$ & $0.763 \%$ & $1.419 \%$ & $2.581 \%$ & $3.756 \%$ & $3.583 \%$ \\
16 & $0.225 \%$ & $0.453 \%$ & $0.797 \%$ & $1.439 \%$ & $2.520 \%$ & $3.591 \%$ & $3.408 \%$ \\
17 & $0.250 \%$ & $0.488 \%$ & $0.830 \%$ & $1.453 \%$ & $2.460 \%$ & $3.436 \%$ & $3.252 \%$ \\
18 & $0.276 \%$ & $0.521 \%$ & $0.860 \%$ & $1.464 \%$ & $2.400 \%$ & $3.292 \%$ & $3.109 \%$ \\
19 & $0.302 \%$ & $0.554 \%$ & $0.888 \%$ & $1.471 \%$ & $2.341 \%$ & $3.158 \%$ & $2.979 \%$ \\
20 & $0.329 \%$ & $0.586 \%$ & $0.913 \%$ & $1.475 \%$ & $2.284 \%$ & $3.033 \%$ & $2.860 \%$ \\
\hline
\end{tabular}


Table V

\section{Recovery Rates*}

The table shows the percentage of par that a bond is worth one month after bankruptcy, given the rating shown in the first column.

\begin{tabular}{lr}
\hline Original Rating & Recovery Rate \\
\hline AAA & $68.34 \%$ \\
AA & $59.59 \%$ \\
A & $60.63 \%$ \\
BBB & $49.42 \%$ \\
BB & $39.05 \%$ \\
B & $37.54 \%$ \\
CCC & $38.02 \%$ \\
Default & $0 \%$ \\
\hline
\end{tabular}

*From Altman and Vellore (1998) 


\section{Table VI}

\section{Mean, Minimum and Maximum Spreads assuming Risk Neutrality}

This table shows the spread of corporate spot rates over government spot rates when taxes are assumed to be zero, but default rates and recovery rates are taken into account. The corporate forward rates are computed using equation (6). These forward rates are converted to spot rates, which are then used to compute the spreads below.

Panel (A) : Mean Spreads

\begin{tabular}{lrrrrrrrrrr}
\hline years & 1 & 2 & 3 & 4 & 5 & 6 & 7 & 8 & 9 & 10 \\
\hline AA & $0.000 \%$ & $0.004 \%$ & $0.008 \%$ & $0.012 \%$ & $0.017 \%$ & $0.023 \%$ & $0.028 \%$ & $0.034 \%$ & $0.041 \%$ & $0.048 \%$ \\
A & $0.043 \%$ & $0.053 \%$ & $0.063 \%$ & $0.074 \%$ & $0.084 \%$ & $0.095 \%$ & $0.106 \%$ & $0.117 \%$ & $0.128 \%$ & $0.140 \%$ \\
BBB & $0.110 \%$ & $0.145 \%$ & $0.181 \%$ & $0.217 \%$ & $0.252 \%$ & $0.286 \%$ & $0.319 \%$ & $0.351 \%$ & $0.380 \%$ & $0.409 \%$ \\
\hline
\end{tabular}

Panel (B) : Minimum Spreads

\begin{tabular}{|c|c|c|c|c|c|c|c|c|c|c|}
\hline years & 1 & 2 & 3 & 4 & 5 & 6 & 7 & 8 & 9 & 10 \\
\hline AA & $0.000 \%$ & $0.003 \%$ & $0.007 \%$ & $0.011 \%$ & $0.015 \%$ & $0.020 \%$ & $0.025 \%$ & $0.031 \%$ & $0.038 \%$ & $0.044 \%$ \\
\hline A & $0.038 \%$ & $0.046 \%$ & $0.055 \%$ & $0.063 \%$ & $0.073 \%$ & $0.083 \%$ & $0.093 \%$ & $0.104 \%$ & $0.116 \%$ & $0.128 \%$ \\
\hline BBB & $0.101 \%$ & $0.132 \%$ & $0.164 \%$ & $0.197 \%$ & $0.229 \%$ & $0.262 \%$ & $0.294 \%$ & $0.326 \%$ & $0.356 \%$ & $0.385 \%$ \\
\hline
\end{tabular}

Panel (C) : Maximum Spreads

\begin{tabular}{lrrrrrrrrrr}
\hline years & 1 & 2 & 3 & 4 & 5 & 6 & 7 & 8 & 9 & 10 \\
\hline AA & $0.000 \%$ & $0.004 \%$ & $0.009 \%$ & $0.014 \%$ & $0.019 \%$ & $0.025 \%$ & $0.031 \%$ & $0.038 \%$ & $0.044 \%$ & $0.051 \%$ \\
A & $0.047 \%$ & $0.059 \%$ & $0.071 \%$ & $0.083 \%$ & $0.094 \%$ & $0.106 \%$ & $0.117 \%$ & $0.129 \%$ & $0.140 \%$ & $0.151 \%$ \\
BBB & $0.118 \%$ & $0.156 \%$ & $0.196 \%$ & $0.235 \%$ & $0.273 \%$ & $0.309 \%$ & $0.342 \%$ & $0.374 \%$ & $0.403 \%$ & $0.431 \%$ \\
\hline
\end{tabular}




\section{Table VII}

\section{Mean, Minimum and Maximum Spreads with Taxes assuming Risk Neutrality}

This table shows the spread of corporate spot rates over government spot rates when taxes as well as default rates and recovery rates are taken into account. The corporate forward rates are computed using equation (9). These forward rates are converted to spot rates, which are then used to compute the spreads below.

Panel (A) : Mean Spreads with effective tax rate of $4.875 \%$

\begin{tabular}{lcccccccccc}
\hline years & 1 & 2 & 3 & 4 & 5 & 6 & 7 & 8 & 9 & 10 \\
\hline AA & $0.358 \%$ & $0.362 \%$ & $0.366 \%$ & $0.370 \%$ & $0.375 \%$ & $0.379 \%$ & $0.383 \%$ & $0.388 \%$ & $0.393 \%$ & $0.398 \%$ \\
A & $0.399 \%$ & $0.410 \%$ & $0.419 \%$ & $0.429 \%$ & $0.438 \%$ & $0.448 \%$ & $0.457 \%$ & $0.466 \%$ & $0.476 \%$ & $0.486 \%$ \\
BBB & $0.467 \%$ & $0.501 \%$ & $0.535 \%$ & $0.568 \%$ & $0.601 \%$ & $0.632 \%$ & $0.662 \%$ & $0.691 \%$ & $0.718 \%$ & $0.744 \%$ \\
\hline
\end{tabular}

Panel (B) : Mean Spreads with effective tax rate of $4.0 \%$

\begin{tabular}{|c|c|c|c|c|c|c|c|c|c|c|}
\hline & 1 & 2 & 3 & 4 & 1 & 6 & 7 & 8 & 9 & 10 \\
\hline AA & $92 \%$ & $296^{\circ}$ & $01 \%$ & $05 \%$ & $0.309 \%$ & $0.314 \%$ & $19 \%$ & $24 \%$ & $\begin{array}{l}0.329 \% \\
\end{array}$ & $0.335 \%$ \\
\hline A & $334 \%$ & $.344 \%$ & $354 \%$ & $0.364 \%$ & $0.374 \%$ & $0.383 \%$ & $0.393 \%$ & $0.403 \%$ & $0.413 \%$ & $0.423 \%$ \\
\hline BBB & $0.402 \%$ & $0.436 \%$ & $0.470 \%$ & $0.504 \%$ & $0.537 \%$ & $0.569 \%$ & $0.600 \%$ & $0.629 \%$ & $0.657 \%$ & $0.683 \%$ \\
\hline
\end{tabular}

Panel (C) : Mean Spreads with effective tax rate of $6.7 \%$

\begin{tabular}{lrrrrrrrrrr}
\hline \multicolumn{1}{c}{ years } & 1 & 2 & 3 & 4 & 5 & 6 & 7 & 8 & 9 & 10 \\
\hline AA & $0.496 \%$ & $0.501 \%$ & $0.505 \%$ & $0.508 \%$ & $0.512 \%$ & $0.516 \%$ & $0.520 \%$ & $0.524 \%$ & $0.528 \%$ & $0.532 \%$ \\
A & $0.537 \%$ & $0.547 \%$ & $0.557 \%$ & $0.566 \%$ & $0.575 \%$ & $0.583 \%$ & $0.592 \%$ & $0.600 \%$ & $0.609 \%$ & $0.618 \%$ \\
BBB & $0.606 \%$ & $0.639 \%$ & $0.672 \%$ & $0.704 \%$ & $0.735 \%$ & $0.765 \%$ & $0.794 \%$ & $0.821 \%$ & $0.847 \%$ & $0.871 \%$ \\
\hline
\end{tabular}




\section{Table VIII}

\section{Relationship between Unexplained Spreads and Treasury Term Structure}

This table shows the results of regression of Unexplained Spreads on two variables summarizing the information contained in the treasury term structure. These two variables are (a) the term spread defined as the difference of 10 year treasury spot rate and 2 year treasury spot rate and (b) the two year treasury spot rate. The results reported are for Industrial Corporate bonds. Similar results were obtained for Corporate bonds issued by Financial firms. Values in parentheses are $t$-values.

Panel A : Industrial AA rated bonds

\begin{tabular}{|c|c|c|c|c|}
\hline $\begin{array}{l}\text { Maturity } \\
\text { in years }\end{array}$ & Constant & $\begin{array}{l}\text { (10year-2year) } \\
\text { Treasury rate }\end{array}$ & $\begin{array}{l}2 \text { year } \\
\text { Treasury rate }\end{array}$ & $\operatorname{Adj}-R^{2}$ \\
\hline 2 & $\begin{array}{l}-0.1276 \\
(-1.348)\end{array}$ & $\begin{array}{l}0.0681 \\
(3.145)\end{array}$ & $\begin{array}{l}0.0262 \\
(2.277)\end{array}$ & 0.0625 \\
\hline 3 & $\begin{array}{l}-0.0113 \\
(-0.116)\end{array}$ & $\begin{array}{l}0.0200 \\
(0.901)\end{array}$ & $\begin{array}{l}0.0166 \\
(1.403)\end{array}$ & 0.0004 \\
\hline 4 & $\begin{array}{l}-0.0982 \\
(-1.102)\end{array}$ & $\begin{array}{l}0.0188 \\
(0.923)\end{array}$ & $\begin{array}{r}0.0354 \\
(3.265)\end{array}$ & 0.1105 \\
\hline 5 & $\begin{array}{l}-0.2234 \\
(-2.725)\end{array}$ & $\begin{array}{l}0.0301 \\
(1.604)\end{array}$ & $\begin{array}{r}0.0582 \\
(5.837)\end{array}$ & 0.3054 \\
\hline 6 & $\begin{array}{l}-0.3394 \\
(-4.205)\end{array}$ & $\begin{array}{l}0.0429 \\
(2.324)\end{array}$ & $\begin{array}{r}0.0784 \\
(7.985)\end{array}$ & 0.4496 \\
\hline 7 & $\begin{array}{l}-0.4364 \\
(-5.211)\end{array}$ & $\begin{array}{l}0.0542 \\
(2.831)\end{array}$ & $\begin{array}{l}0.0948 \\
(9.309)\end{array}$ & 0.5225 \\
\hline 8 & $\begin{array}{l}-0.5155 \\
(-5.817)\end{array}$ & $\begin{array}{l}0.0636 \\
(3.138)\end{array}$ & $\begin{array}{r}0.1080 \\
(10.013)\end{array}$ & 0.5558 \\
\hline 9 & $\begin{array}{l}-0.5802 \\
(-6.179)\end{array}$ & $\begin{array}{r}0.0712 \\
(3.316)\end{array}$ & $\begin{array}{r}0.1184 \\
(10.368)\end{array}$ & 0.5708 \\
\hline 10 & $\begin{array}{l}-0.6342 \\
(-6.409)\end{array}$ & $\begin{array}{r}0.0775 \\
(3.423)\end{array}$ & $\begin{array}{r}0.1270 \\
(10.548) \\
\end{array}$ & 0.5776 \\
\hline
\end{tabular}

Panel B : Industrial A rated bonds

\begin{tabular}{|c|c|c|c|c|}
\hline $\begin{array}{c}\text { Maturity } \\
\text { in years }\end{array}$ & $\begin{array}{r}\text { Constant ( } \\
\mathrm{T}\end{array}$ & $\begin{array}{l}-2 \text { year) } \\
\text { y rate }\end{array}$ & $\begin{array}{l}2 \text { year } \\
\text { Treasury rate }\end{array}$ & $\overline{A d j}-R^{2}$ \\
\hline 2 & $\begin{array}{l}-0.5545 \\
-(3.855)\end{array}$ & $\begin{array}{c}0.2063 \\
(6.270)\end{array}$ & $\begin{array}{r}0.0933 \\
(5.328)\end{array}$ & 0.2418 \\
\hline 3 & $\begin{array}{l}-0.5092 \\
-(4.117)\end{array}$ & $\begin{array}{r}0.1690 \\
(5.974)\end{array}$ & $\begin{array}{l}0.1004 \\
(6.671)\end{array}$ & 0.2711 \\
\hline 4 & $\begin{array}{l}-0.4813 \\
-(4.246)\end{array}$ & $\begin{array}{l}0.1531 \\
(5.906)\end{array}$ & $\begin{array}{l}0.1028 \\
(7.455)\end{array}$ & 0.3107 \\
\hline 5 & $\begin{array}{l}-0.4648 \\
-(4.377)\end{array}$ & $\begin{array}{l}0.1458 \\
(6.002)\end{array}$ & $\begin{array}{l}0.1035 \\
(8.015)\end{array}$ & 0.3436 \\
\hline 6 & $\begin{array}{l}-0.4557 \\
-(4.426)\end{array}$ & $\begin{array}{l}0.1419 \\
(6.027)\end{array}$ & $\begin{array}{r}0.1037 \\
(8.280)\end{array}$ & 0.3596 \\
\hline 7 & $\begin{array}{l}-0.4516 \\
-(4.401)\end{array}$ & $\begin{array}{r}0.1396 \\
(5.950)\end{array}$ & $\begin{array}{l}0.1037 \\
(8.305)\end{array}$ & 0.3617 \\
\hline 8 & $\begin{array}{l}-0.4509 \\
-(4.341)\end{array}$ & $\begin{array}{l}0.1381 \\
(5.815)\end{array}$ & $\begin{array}{l}0.1036 \\
(8.199)\end{array}$ & 0.3561 \\
\hline 9 & $\begin{array}{l}-0.4526 \\
-(4.278)\end{array}$ & $\begin{array}{r}0.137 \\
(5.663)\end{array}$ & $\begin{array}{l}0.1035 \\
(8.044)\end{array}$ & 0.3474 \\
\hline 10 & $\begin{array}{l}-0.4559 \\
-(4.223)\end{array}$ & $\begin{array}{l}0.1362 \\
(5.516)\end{array}$ & $\begin{array}{l}0.1035 \\
(7.878)\end{array}$ & 0.3380 \\
\hline
\end{tabular}


Panel C : Industrial BBB rated bonds

\begin{tabular}{|c|c|c|c|c|}
\hline \multirow{2}{*}{$\begin{array}{c}\text { Maturity } \\
\text { in years }\end{array}$} & \multicolumn{2}{|c|}{$\begin{array}{c}\text { Constant (10year-2year) } \\
\text { Treasury rate }\end{array}$} & $\begin{array}{l}2 \text { year } \\
\text { Treasury rate }\end{array}$ & $\operatorname{Adj}-R^{2}$ \\
\hline & -1.0993 & 0.5513 & 0.1881 & 0.4594 \\
\hline & $-(4.543)$ & $(9.961)$ & $(6.391)$ & \\
\hline \multirow[t]{2}{*}{3} & -0.9788 & 0.5158 & 0.1761 & 0.489 \\
\hline & $-(4.584)$ & $(10.562)$ & $(6.780)$ & \\
\hline \multirow[t]{2}{*}{4} & -0.8794 & 0.4528 & 0.1672 & 0.4579 \\
\hline & $-(4.468)$ & (10.059) & (6.983) & \\
\hline \multirow[t]{2}{*}{5} & -0.8088 & 0.3939 & 0.1607 & 0.4136 \\
\hline & $-(4.353)$ & $(9.270)$ & (7.110) & \\
\hline \multirow[t]{2}{*}{6} & -0.7623 & 0.3459 & 0.1559 & 0.3658 \\
\hline & $-(4.204)$ & $(8.341)$ & (7.069) & \\
\hline \multirow[t]{2}{*}{7} & -0.7332 & 0.3081 & 0.1524 & 0.3228 \\
\hline & $-(4.044)$ & $(7.430)$ & (6.908) & \\
\hline \multirow[t]{2}{*}{8} & -0.7161 & 0.2784 & 0.1496 & 0.2885 \\
\hline & $-(3.900)$ & (6.629) & (6.700) & \\
\hline \multirow[t]{2}{*}{9} & -0.7072 & 0.2547 & 0.1475 & 0.2628 \\
\hline & $-(3.785)$ & (5.961) & (6.489) & \\
\hline \multirow[t]{2}{*}{10} & -0.7039 & 0.2356 & 0.1458 & 0.2442 \\
\hline & $-(3.699)$ & (5.414) & $(6.297)$ & \\
\hline
\end{tabular}


Table IX

\section{Relationship between Returns and Fama-French Risk Factors}

This table shows the results of the regression of Returns due to a change in the unexplained spread on the Fama-French Risk Factors, viz. (a) the market excess return (over T-bills) factor (b) the Small Minus Big factor and (c) the High Minus Low book to market factor. The results reported below are for Industrial Corporate bonds. Similar results were obtained for bonds of Financial Firms. The values in parentheses are $t$-values.

Panel A: Industrial AA rated bonds

\begin{tabular}{crrrrr}
\hline Maturity & Constant & Market & SMB & HML & Adj-R $^{2}$ \\
\hline 2 & -0.0046 & 0.0773 & 0.1192 & -0.0250 & 0.0986 \\
& $-(0.297)$ & $(2.197)$ & $(2.318)$ & $-(0.404)$ & \\
3 & -0.0066 & 0.1103 & 0.2045 & 0.0518 & 0.0858 \\
& $-(0.286)$ & $(2.114)$ & $(2.680)$ & $(0.563)$ & \\
4 & -0.0058 & 0.1238 & 0.2626 & 0.0994 & 0.0846 \\
& $-(0.210)$ & $(1.983)$ & $(2.877)$ & $(0.903)$ & \\
5 & -0.0034 & 0.1260 & 0.3032 & 0.1261 & 0.0801 \\
& $-(0.109)$ & $(1.791)$ & $(2.949)$ & $(1.018)$ & \\
6 & -0.0001 & 0.1222 & 0.3348 & 0.1414 & 0.0608 \\
& $-(0.003)$ & $(1.463)$ & $(2.742)$ & $(0.961)$ & \\
7 & 0.0035 & 0.1157 & 0.3621 & 0.1514 & 0.0374 \\
& $(0.077)$ & $(1.116)$ & $(2.391)$ & $(0.829)$ & \\
8 & 0.0073 & 0.1080 & 0.3873 & 0.1586 & 0.0195 \\
& $(0.129)$ & $(0.839)$ & $(2.059)$ & $(0.700)$ & \\
9 & 0.0112 & 0.0996 & 0.4119 & 0.1650 & 0.0076 \\
& $(0.163)$ & $(0.635)$ & $(1.798)$ & $(0.598)$ & \\
10 & 0.0151 & 0.0912 & 0.4356 & 0.1704 & -0.0002 \\
& $(0.184)$ & $(0.489)$ & $(1.598)$ & $(0.519)$ & \\
\hline
\end{tabular}

Panel B: Industrial A rated bonds

\begin{tabular}{crrrrr}
\hline Maturity & Constant & Market & SMB & HML & Adj-R \\
\hline 2 & -0.0081 & 0.1353 & 0.1831 & 0.0989 & 0.1372 \\
& $-(0.437)$ & $(3.202)$ & $(2.965)$ & $(1.329)$ & \\
3 & -0.0119 & 0.1847 & 0.3072 & 0.1803 & 0.2068 \\
& $-(0.534)$ & $(3.631)$ & $(4.134)$ & $(2.013)$ & \\
4 & -0.0123 & 0.2178 & 0.3911 & 0.2619 & 0.2493 \\
& $-(0.501)$ & $(3.904)$ & $(4.796)$ & $(2.666)$ & \\
5 & -0.0105 & 0.2419 & 0.4498 & 0.3424 & 0.2754 \\
& $-(0.403)$ & $(4.068)$ & $(5.176)$ & $(3.270)$ & \\
6 & -0.0077 & 0.2616 & 0.4952 & 0.4222 & 0.2647 \\
& $-(0.262)$ & $(3.899)$ & $(5.050)$ & $(3.573)$ & \\
7 & -0.0044 & 0.2792 & 0.5345 & 0.5014 & 0.226 \\
& $-(0.125)$ & $(3.480)$ & $(4.560)$ & $(3.549)$ & \\
8 & -0.0009 & 0.2958 & 0.5709 & 0.5805 & 0.1828 \\
& $-(0.020)$ & $(3.032)$ & $(4.003)$ & $(3.378)$ & \\
9 & 0.0028 & 0.3121 & 0.6059 & 0.6596 & 0.1469 \\
& $(0.053)$ & $(2.654)$ & $(3.525)$ & $(3.185)$ & \\
10 & 0.0064 & 0.3282 & 0.6407 & 0.7385 & 0.1198 \\
& $(0.105)$ & $(2.357)$ & $(3.149)$ & $(3.012)$ & \\
\hline \multirow{2}{*}{5} & & & & &
\end{tabular}




\begin{tabular}{crrrrr}
\multicolumn{7}{c}{ Panel C: Industrial BBB rated bonds } \\
\hline Maturity & Constant & Market & SMB & HML & Adj-R \\
\hline 2 & 0.0083 & 0.1112 & 0.3401 & 0.1259 & 0.0969 \\
& $(0.276)$ & $(1.626)$ & $(3.403)$ & $(1.045)$ & \\
3 & 0.0094 & 0.1691 & 0.4656 & 0.2922 & 0.1263 \\
& $(0.255)$ & $(2.010)$ & $(3.787)$ & $(1.972)$ & \\
4 & 0.0084 & 0.2379 & 0.5836 & 0.4605 & 0.1798 \\
& $(0.209)$ & $(2.601)$ & $(4.365)$ & $(2.858)$ & \\
5 & 0.0062 & 0.3132 & 0.6987 & 0.6263 & 0.2585 \\
& $(0.153)$ & $(3.406)$ & $(5.199)$ & $(3.867)$ & \\
6 & 0.0034 & 0.3919 & 0.8127 & 0.7901 & 0.3126 \\
& $(0.080)$ & $(4.025)$ & $(5.711)$ & $(4.607)$ & \\
7 & 0.0004 & 0.4720 & 0.9260 & 0.9522 & 0.3122 \\
& $(0.008)$ & $(4.147)$ & $(5.567)$ & $(4.750)$ & \\
8 & -0.0028 & 0.5528 & 1.0395 & 1.1139 & 0.2807 \\
& $-(0.045)$ & $(3.951)$ & $(5.084)$ & $(4.520)$ & \\
9 & -0.006 & 0.6341 & 1.1529 & 1.2754 & 0.2445 \\
& $-(0.079)$ & $(3.685)$ & $(4.585)$ & $(4.209)$ & \\
10 & -0.0092 & 0.7154 & 1.2662 & 1.4370 & 0.2136 \\
& $-(0.101)$ & $(3.446)$ & $(4.173)$ & $(3.930)$ & \\
\hline \multirow{4}{*}{5}
\end{tabular}


Figure(1) : Empirical Spreads on Industrial Bonds of Six Years Maturity

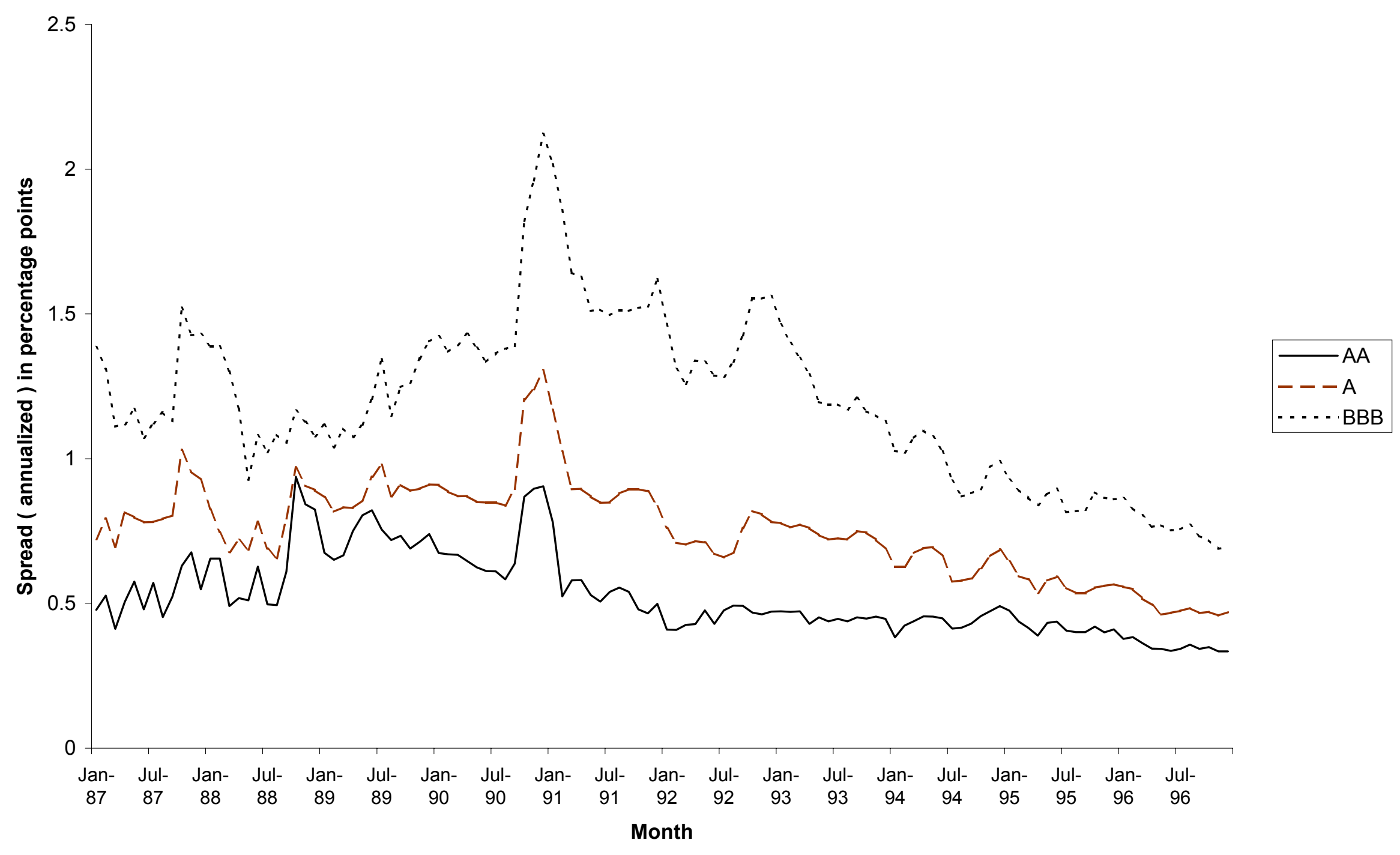




\section{Figure(2) : Spot rates for A rated Industrial Bonds and for Treasuries}

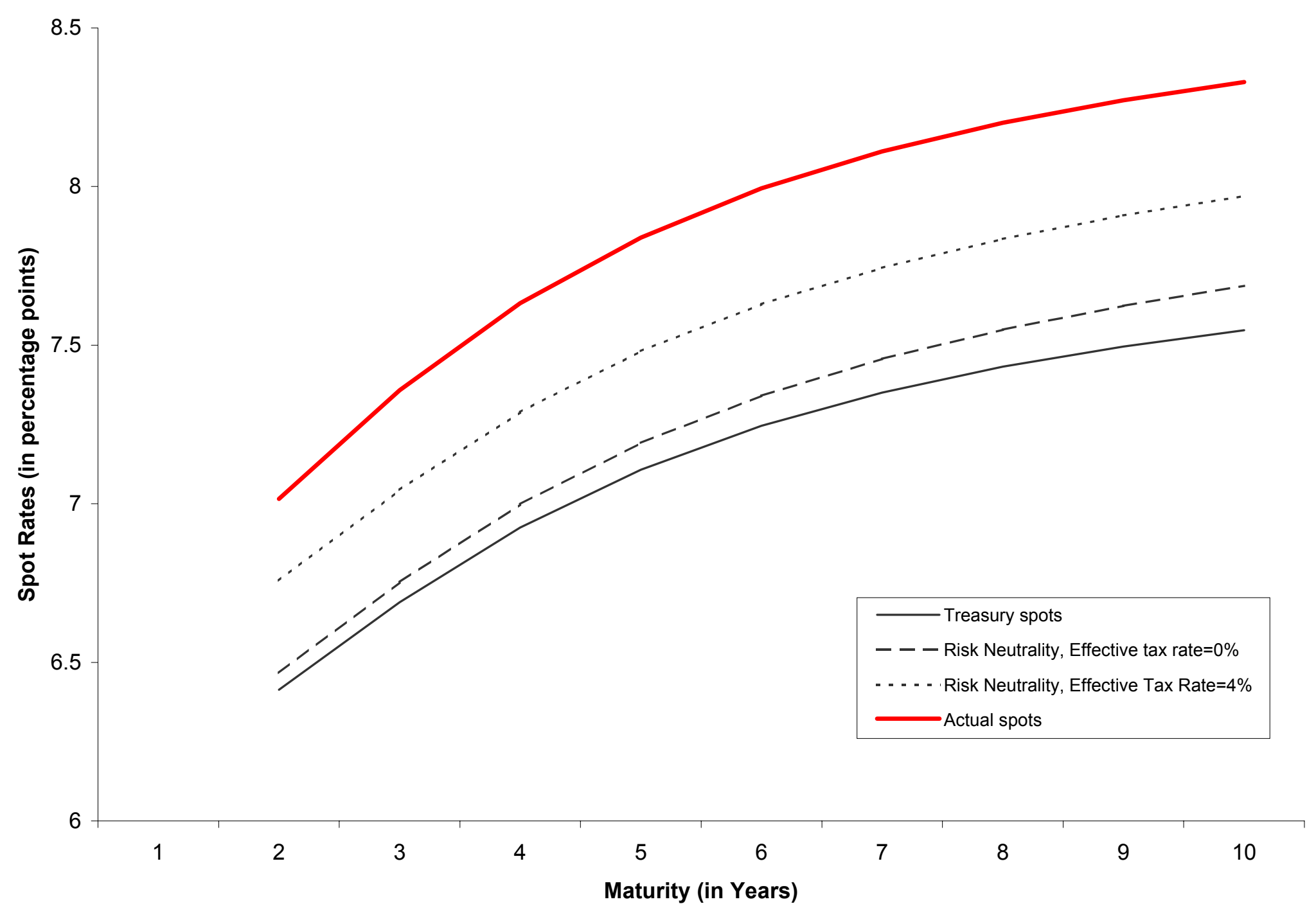

